Supporting Information

\title{
Tandem Catalysts Combining Polymer Synthesis, Post- Polymerization Modification, and Vitrimer Formation
}

Guifu Si, ${ }^{a} \neq$ Meizhou Qi, ${ }^{a} \neq$ Chen Tan, ${ }^{b *}$ and Changle Chen ${ }^{a *}$

${ }^{a}$ CAS Key Laboratory of Soft Matter Chemistry, Hefei National Laboratory for Physical Sciences at the Microscale, Department of Polymer Science and Engineering, University of Science and Technology of China, Hefei, 230026, China.

${ }^{b}$ Institutes of Physical Science and Information Technology, Key Laboratory of Structure and Functional Regulation of Hybrid Materials of Ministry of Education, Anhui University, Hefei, Anhui 230601, China.

\section{Content}

1. Experimental .2

2. Tables. .6

3. Schemes

4. Figures. . .8

5. References .31 


\section{Experimental}

\section{General.}

All chemicals including solvents were purchased from Sinopharm, Energy Chemical, J\&K Chemical and Nine Ding Chemistry Shanghai Co. Ltd.. Deuterated solvents (all 99.5 atom \%D) were purchased from J\&K Chemical Ltd. and dehydrated with $4 \AA$ molecular sieves. THF was distilled from drying over Na. Epoxide monomers were distilled from drying over $\mathrm{CaH}_{2}$. Cyclic anhydrides were purified by the precipitation in the mixture of THF and hexanes. The Mn-salen catalysts En-Mn and Ph-Mn were prepared according to literature methods. ${ }^{1}$ The Mn-salen catalyst $\mathbf{C y}-\mathbf{M n}$ was purchased from J\&K Chemical (a 1/1 mixture of (S,S)- and (R,R)-Jacobsen's catalysts). The monomer $\mathbf{2 a}$ was synthesized via literature method. ${ }^{2}$

${ }^{1} \mathrm{H}$ NMR spectra were recorded by a Bruker Ascend Tm 400 spectrometer at ambient temperature. ${ }^{1} \mathrm{H}$ NMR chemical shifts were referenced to residual deuterated solvent peaks or the tetramethylsilane signal $(0 \mathrm{ppm})$. Molecular weights and molecular weight distributions were determined by size-exclusion chromatography (SEC) employing a series of two linear Styragel columns (HR2 and HR4) at an oven temperature of $45^{\circ} \mathrm{C}$. A Waters 1515 pump and Waters 2414 differential refractive index detector $\left(30^{\circ} \mathrm{C}\right)$ were used. The eluent was THF at a flow rate of $1.0 \mathrm{~mL} / \mathrm{min}$. A series of low dispersity polystyrene standards was used for calibration. Differential scanning calorimetry (DSC) measurements were performed by using a TA Instruments Discovery DSC under a nitrogen atmosphere. Tensile testing was performed using a Minimat Tensile Tester. FT-IR spectra were obtained using a Bruker Alpha Platinum ATR 
spectrometer. Matrixassisted laser desorption/ionization time-of-flight mass spectroscopy (MALDI-TOF MS) was recorded on a Bruker Atouflex Speed. Dithranol was used as matrix, and dichloromethane was used as solvent, and $\mathrm{NaI}$ was added as the cation source. Stress relaxation experiments were conducted in an DMA Q800 V21.3 Build 96 . After a 20 min temperature equilibration $\left(190^{\circ} \mathrm{C}\right)$, a $5 \%$ strain step was applied. The stress was monitored over time. A constant normal force was applied throughout the measurement to ensure a good contact of the material with the geometries. The $5 \%$ deformations were within the linear range using strain sweep experiments.

\section{General procedure for ring-opening copolymerization.}

Certain amounts of monomers, catalyst and initiator were mixed with THF in a flask. The mixture was stirred for $24 \mathrm{~h}$ at given temperature. All the volatiles (THF and the remaining epoxide) were removed under vacuum at $60{ }^{\circ} \mathrm{C}$. The crude unsaturated polyesters were directly used for the subsequent epoxidation reactions. They can be further purified by precipitation using a mixture of $\mathrm{CH}_{2} \mathrm{Cl}_{2}$ and hexanes for NMR analysis.

\section{General procedure for epoxidation.}

The crude unsaturated polyester obtained in the ROCOP step was dissolved in $\mathrm{CH}_{2} \mathrm{Cl}_{2}$ before adding an aqueous solution of $\mathrm{NaClO}(0.55 \mathrm{M}, 5.0$ equiv. based on anhydride repeat unit) and $\mathrm{Na}_{2} \mathrm{HPO}_{4}(0.05 \mathrm{M})$ at $4{ }^{\circ} \mathrm{C}$. After vigorous stirring for a given time at room temperature, the mixture was allowed to stand for at least $2 \mathrm{~h}$ before removing the aqueous phase. The organic phase was dried over $\mathrm{Na}_{2} \mathrm{SO}_{4}$. The solvent 
was removed under vacuum to generate the epoxy-functionalized polyesters containing residual Mn catalysts. The epoxy-functionalized polyesters can be further purified by the precipitation using a mixture of $\mathrm{CH}_{2} \mathrm{Cl}_{2}$ and hexanes for NMR analysis.

\section{General procedure for ring-opening aminolysis.}

The crude epoxy-functionalized polyester containing residual Mn catalyst was dissolved in excess aniline (2 equiv. based on the epoxy group) and $\mathrm{CH}_{2} \mathrm{Cl}_{2}$ (500 $\mathrm{mg}$ polymer $\left./ \mathrm{mL} \mathrm{CH}_{2} \mathrm{Cl}_{2}\right)$. $\operatorname{AgOTf}(0.1$ equiv. based on the epoxy group) was added, and the mixture was stirred at room temperature for 3 days. The arylamine-functionalized polyester was obtained by the precipitation in a $\mathrm{CH}_{2} \mathrm{Cl}_{2}$ and hexanes mixture. The resulting polymer was dried under vacuum.

\section{General procedure for curing to generate epoxy resins as well as vitrimers.}

A mixture of all components (for epoxy resins: crude epoxy-functionalized polyester containing residual Mn catalyst, and comonomers; for vitrimers: crude epoxyfunctionalized polyester containing residual Mn catalyst, comonomers, and tetraethylene-glycol) was dissolved in acetone, which was subsequently removed under vacuum at room temperature. The resulting mixture was dried under vacuum for $24 \mathrm{~h}$ at room temperature to generate either viscous liquids or solids, which was transferred into a teflon mold with a dog-bone shape and cured following the procedure $100{ }^{\circ} \mathrm{C} / 2$ $\mathrm{h}+150^{\circ} \mathrm{C} / 2 \mathrm{~h}+170{ }^{\circ} \mathrm{C} / 2 \mathrm{~h}+190^{\circ} \mathrm{C} / 1 \mathrm{~h}$. A silicone grease was used as a release agent. After cooling to room temperature, the samples were taken out.

\section{Lap shear adhesion test.}

The lap shear strip specimens were machined from a stainless steel panel (type 
201) $(100 \times 18 \times 1.0 \mathrm{~mm})$ and treated by soaking in conc. $\mathrm{H}_{2} \mathrm{SO}_{4}$ for $1 \mathrm{~h}$ followed by washing with distilled water, ethanol and dichloromethane. The epoxy resin sample (ca. $50 \mathrm{mg}$ ) was uniformly applied over a bonding area (ca. $\sim 5.0 \mathrm{~mm} \times 18 \mathrm{~mm}$ ) on the stainless steel specimens. After curing $\left(100{ }^{\circ} \mathrm{C} / 2 \mathrm{~h}+150{ }^{\circ} \mathrm{C} / 2 \mathrm{~h}+170{ }^{\circ} \mathrm{C} / 2 \mathrm{~h}+\right.$ $190{ }^{\circ} \mathrm{C} / 1 \mathrm{~h}$ ) and cooling to room temperature, the specimen was used in the lap shear adhesion test. The lap shear strength was calculated by the equation: lap shear strength $(\mathrm{MPa})=$ maximum loading force $(\mathrm{N}) /$ bonding area $\left(\mathrm{mm}^{2}\right)$

\section{Recycling of vitrimers.}

Broken epoxy-anhydride dogbone samples were heated to $150{ }^{\circ} \mathrm{C}$ and ground to powders. After cooling to room temperature, the recycled polymer powders were reprocessed under a heating press (temperature: $200{ }^{\circ} \mathrm{C}$; pressure: $200 \mathrm{MPa}$; time: $1 \mathrm{~h}$ ) in a stainless steel mold (for vitrimer based composites, the packings were mixed with the recycled polymer powders by hand-molding before heating and pressuring). A silicone grease was used as a release agent. After remolding and cooling to room temperature, the recycled samples were taken out for measurements. 


\section{Tables}

Table S1. Epoxidation of unsaturated polyesters.

\begin{tabular}{|c|c|c|c|c|c|c|}
\hline Entry $^{\mathrm{a}}$ & Catalyst & $\begin{array}{l}\text { Anhydride } \\
\text { / Epoxide }\end{array}$ & Time (h) & $\begin{array}{l}\text { Conv. }^{b} \\
(\%)\end{array}$ & $\begin{array}{l}M_{\mathrm{n}}^{\mathrm{c}} \\
(\mathrm{kDa})\end{array}$ & $M_{\mathrm{w}} / M_{\mathrm{n}}^{\mathrm{c}}$ \\
\hline 1 & En-Mn & $1 \mathrm{a} / \mathbf{1 b}$ & 72 & 43 & 6.2 & 1.4 \\
\hline 2 & En-Mn & $1 \mathrm{a} / \mathbf{1 b}$ & 18 & 25 & 5.7 & 1.2 \\
\hline $3^{d}$ & Ph-Mn & $1 \mathrm{a} / 1 \mathrm{~b}$ & 18 & 14 & 5.6 & 1.4 \\
\hline $4^{\mathrm{e}}$ & Cy-Mn & $1 \mathrm{a} / \mathbf{1 b}$ & 18 & 25 & 5.7 & 1.5 \\
\hline $5^{\mathrm{f}}$ & En-Mn & $1 \mathrm{a} / \mathbf{1 b}$ & 18 & 18 & 14.4 & 1.9 \\
\hline $6^{\mathrm{g}}$ & En-Mn & $1 \mathrm{a} / \mathbf{1 b}$ & 18 & N.R. & & \\
\hline $7^{\mathrm{h}}$ & En-Mn & $1 \mathrm{a} / \mathbf{1 b}$ & 18 & 71 & 3.8 & 1.2 \\
\hline $8^{\mathrm{h}}$ & En-Mn & $1 \mathrm{a} / \mathbf{1 b}$ & 48 & 91 & 3.6 & 1.2 \\
\hline $9^{i}$ & En-Mn & $1 \mathrm{a} / 2 \mathrm{~b}$ & 18 & 70 & 3.5 & 1.1 \\
\hline $10^{j}$ & En-Mn & $\mathbf{1 a} / \mathbf{3 b}$ & 48 & 75 & 3.6 & 1.2 \\
\hline $11^{\mathrm{k}}$ & En-Mn & $1 a / 4 b$ & 48 & 24 & 3.7 & 1.2 \\
\hline $12^{1}$ & En-Mn & $2 a / 1 b$ & 48 & 25 & 3.1 & 1.1 \\
\hline
\end{tabular}

${ }^{a}$ Conditions: The polymer generated in table 1 , entry 1 was used, $m_{\text {polymer, } 0}=50 \mathrm{~g} / \mathrm{L}$ in $\mathrm{CH}_{2} \mathrm{Cl}_{2}$, $\mathrm{NaClO} 5.0$ equiv., $[\mathrm{NaClO}]_{0}=0.55 \mathrm{M}$ in $\mathrm{H}_{2} \mathrm{O},\left[\mathrm{Na}_{2} \mathrm{HPO}_{4}\right]=0.05 \mathrm{M}$ in $\mathrm{H}_{2} \mathrm{O}, 25{ }^{\circ} \mathrm{C}$. ${ }^{\mathrm{b}}$ Conversion of

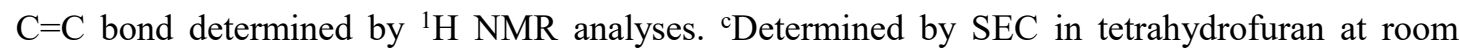
temperature using polystyrene standards. ${ }^{\mathrm{d}}$ The polymer generated in table 1 , entry 2 was used. ${ }^{\mathrm{e}}$ The

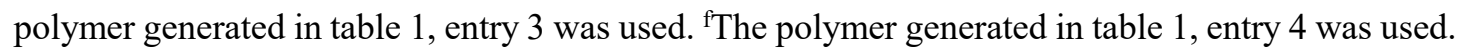
gTHF was used instead of $\mathrm{CH}_{2} \mathrm{Cl}_{2}$. ${ }^{\mathrm{h}}$ The polymer generated in table 1 , entry 5 was used. ${ }^{\text {iThe }}$ polymer generated in table 1 , entry 6 was used. ${ }^{j}$ The polymer generated in table 1 , entry 7 was used. ${ }^{\mathrm{k}}$ The polymer generated in table 1 , entry 8 was used. ${ }^{1}$ The polymer generated in table 1 , entry 9 was used. 


\section{Schemes}

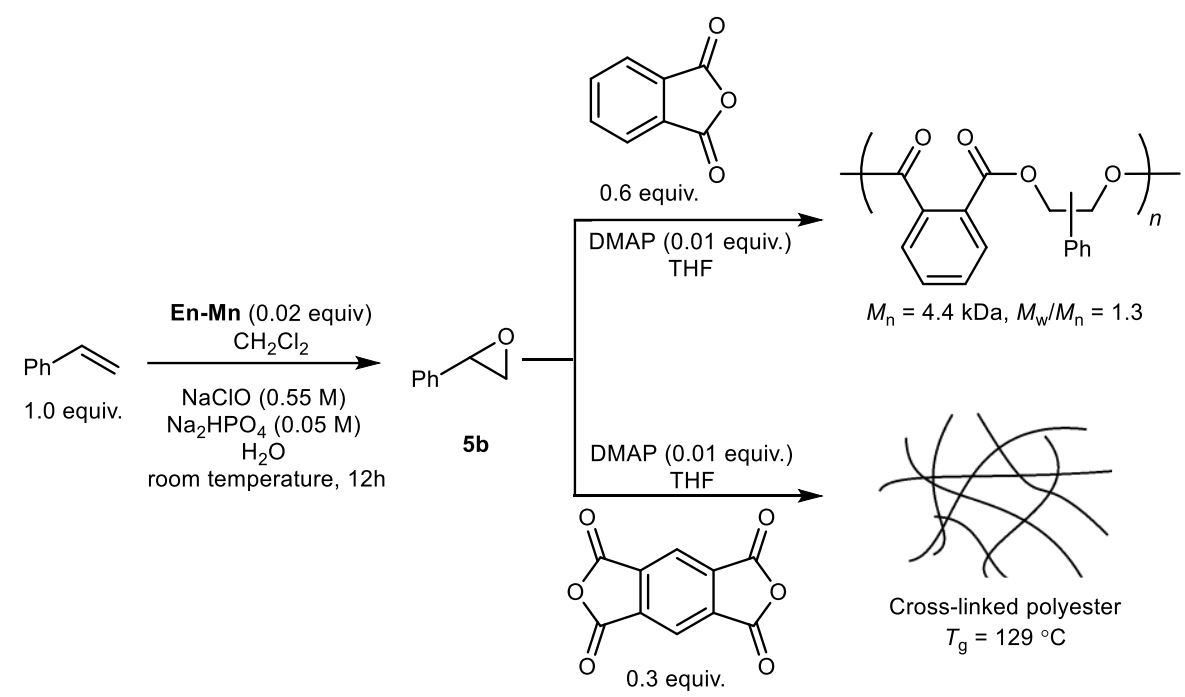

Scheme S1 Mn-salen catalyzed tandem epoxidation to generate epoxide monomer, and subsequent ring-opening copolymerization to generate linear and cross-linked polyesters.

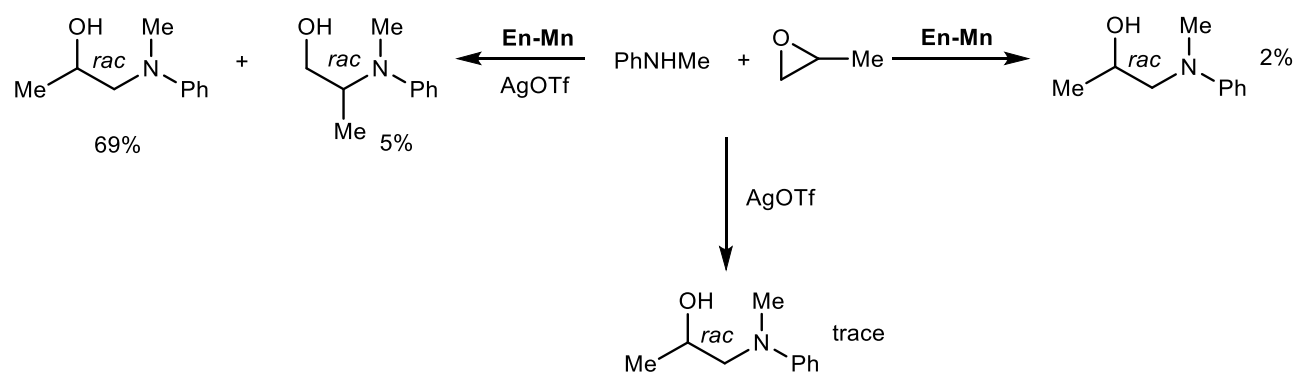

Scheme S2 Mn-salen catalyzed ring-opening aminolysis of propylene oxide with PhNHMe (Conditions: [epoxide]/[PhNHMe $] /\left[\mathrm{Mn}\right.$ or Ag] $=400 / 100 / 1,[\mathrm{PhNHMe}]_{0}=$ $2 \mathrm{M}$ in $\mathrm{CH}_{2} \mathrm{Cl}_{2}, 25{ }^{\circ} \mathrm{C}, 18 \mathrm{~h}$ ) (Yield determined by ${ }^{1} \mathrm{H}$ NMR analyses).

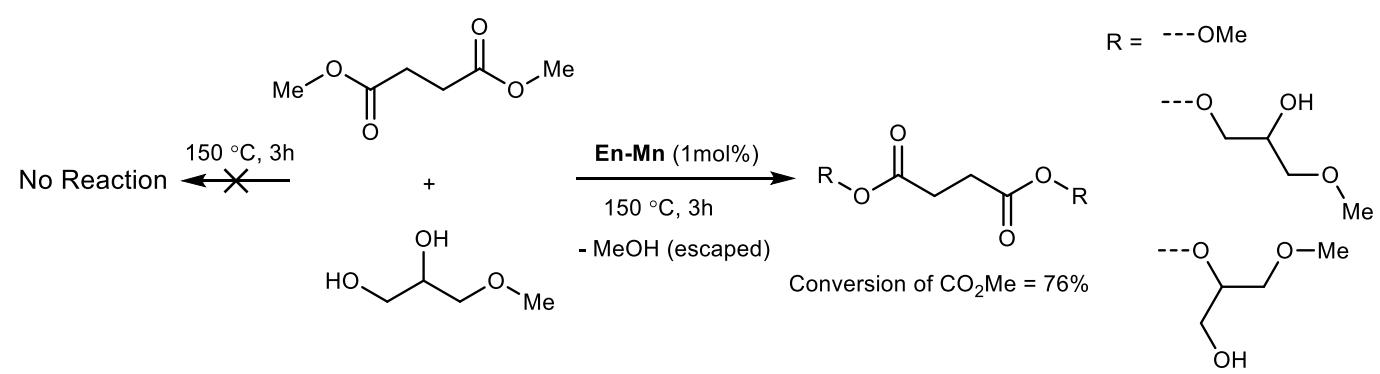

Scheme S3 En-Mn catalyzed transesterification (The conversion of MeO group was determined by ${ }^{1} \mathrm{H}$ NMR analyses). 


\section{Figures}

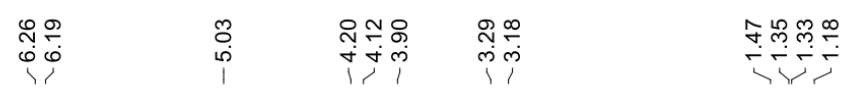
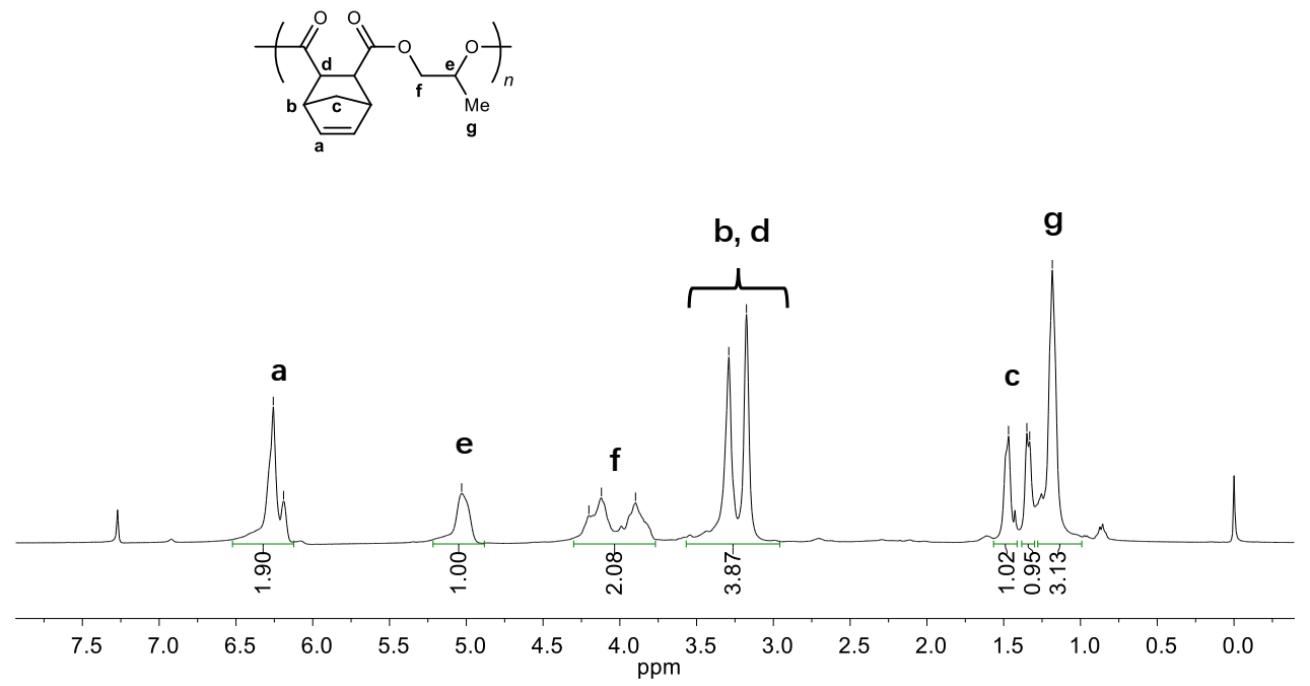

Figure $\mathbf{S 1}{ }^{1} \mathrm{H}$ NMR spectrum of $\mathbf{1 a} / \mathbf{1} \mathbf{b}$ copolymer (containing small amounts of hexanes) (Table 1, entry 1) (400MHz, $\left.\mathrm{CDCl}_{3}, 25^{\circ} \mathrm{C}\right)$.
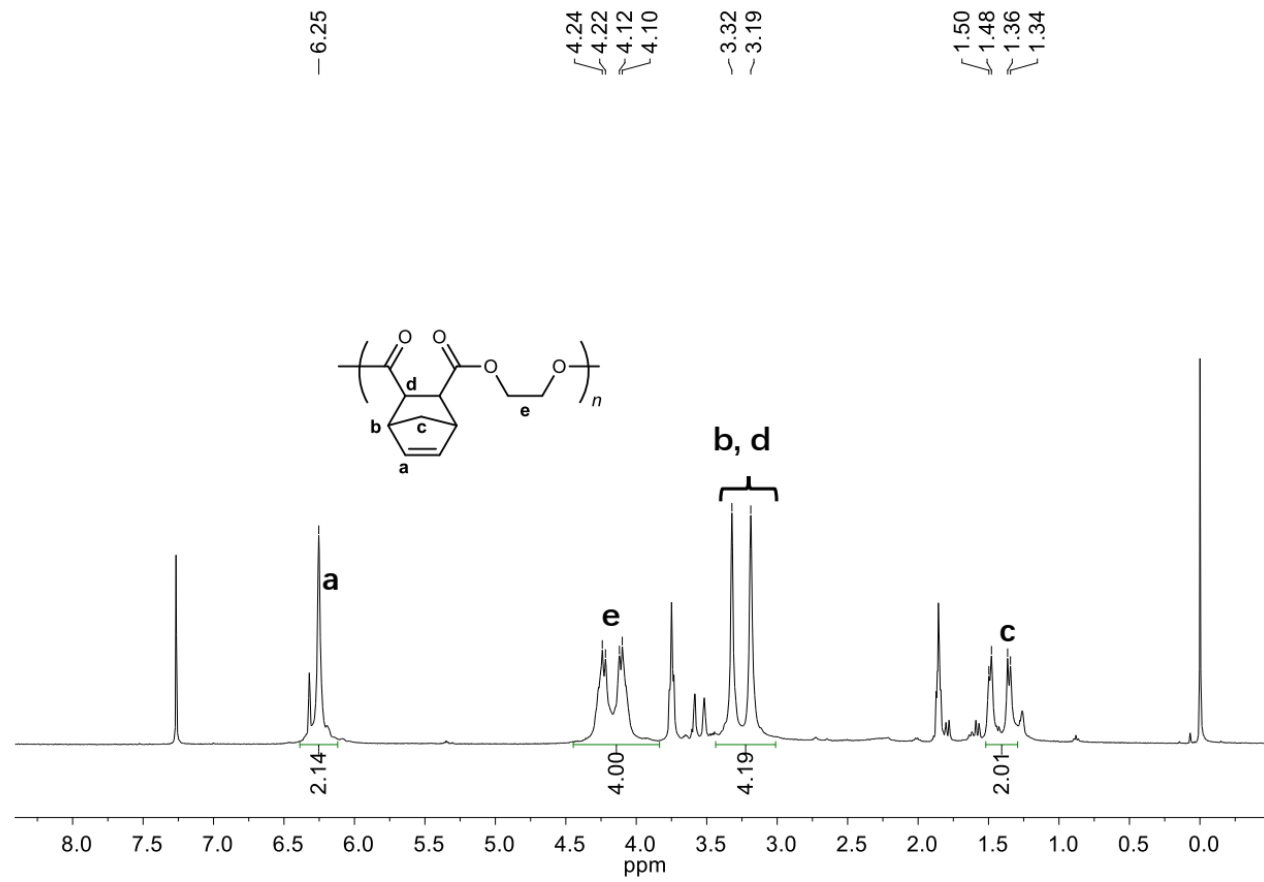

Figure S2 ${ }^{1} \mathrm{H}$ NMR spectrum of $\mathbf{1 a} / \mathbf{2 b}$ copolymer (containing small amounts of THF and hexanes and ca. $7 \mathrm{~mol} \%$ of unreacted 1a) (Table 1, entry 6) $\left(400 \mathrm{MHz}, \mathrm{CDCl}_{3}\right.$, $\left.25^{\circ} \mathrm{C}\right)$. 

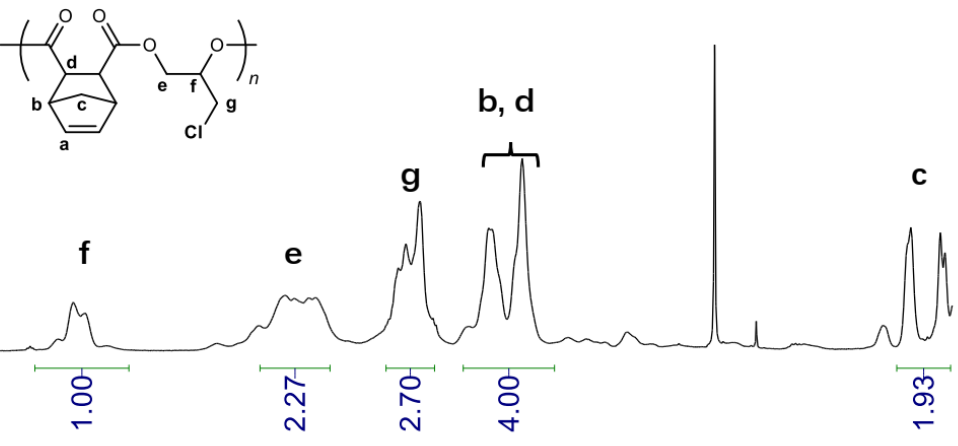

$\begin{array}{llllllllllllll}6.8 & 6.4 & 6.0 & 5.6 & 5.2 & 4.8 & 4.4 & 4.0 & 3.6 & 3.2 & 2.8 & 2.4 & 2.0 & 1.6\end{array}$

Figure $\mathbf{S 3}{ }^{1} \mathrm{H}$ NMR spectrum of $\mathbf{1 a} / \mathbf{3 b}$ copolymer (containing small amounts of toluene and hexanes) (Table 1 , entry 7$)\left(400 \mathrm{MHz}, \mathrm{CDCl}_{3}, 25^{\circ} \mathrm{C}\right)$.

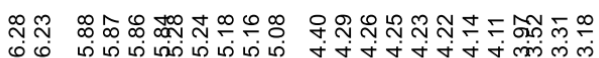

b, d, g, h

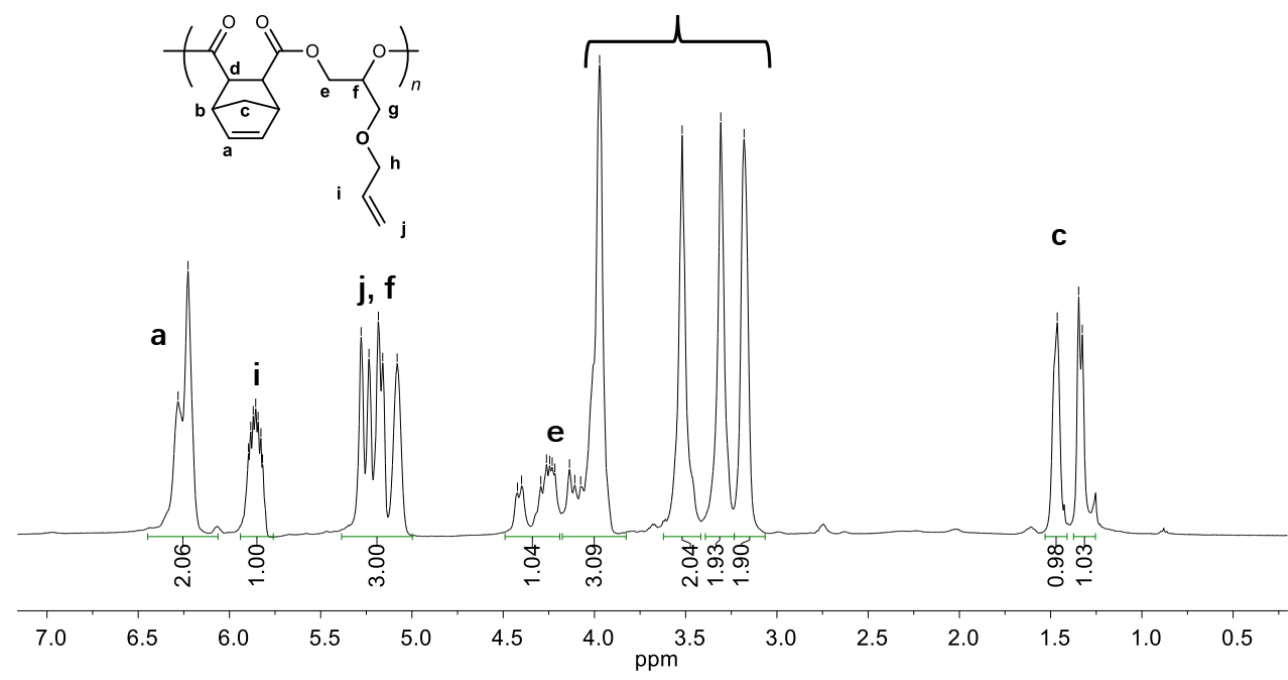

Figure S4 ${ }^{1} \mathrm{H}$ NMR spectrum of $\mathbf{1 a} / \mathbf{4 b}$ copolymer (containing small amounts of hexanes) (Table 1, entry 8) (400MHz, $\left.\mathrm{CDCl}_{3}, 25^{\circ} \mathrm{C}\right)$. 


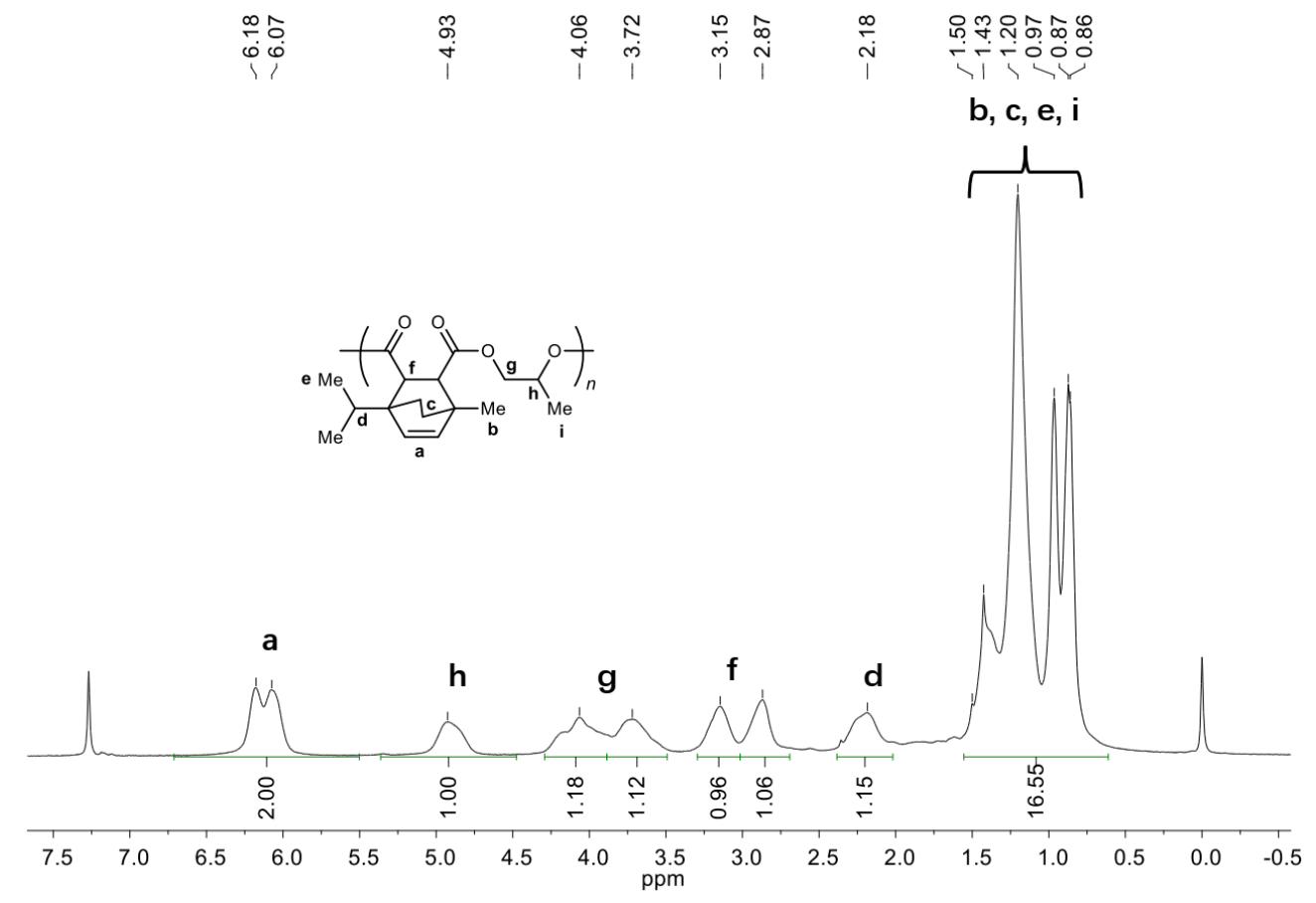

Figure S5 ${ }^{1} \mathrm{H}$ NMR spectrum of $\mathbf{2 a} / \mathbf{1} \mathbf{b}$ copolymer (Table 1, entry 9) (400MHz, $\mathrm{CDCl}_{3}, 25^{\circ} \mathrm{C}$ ). 


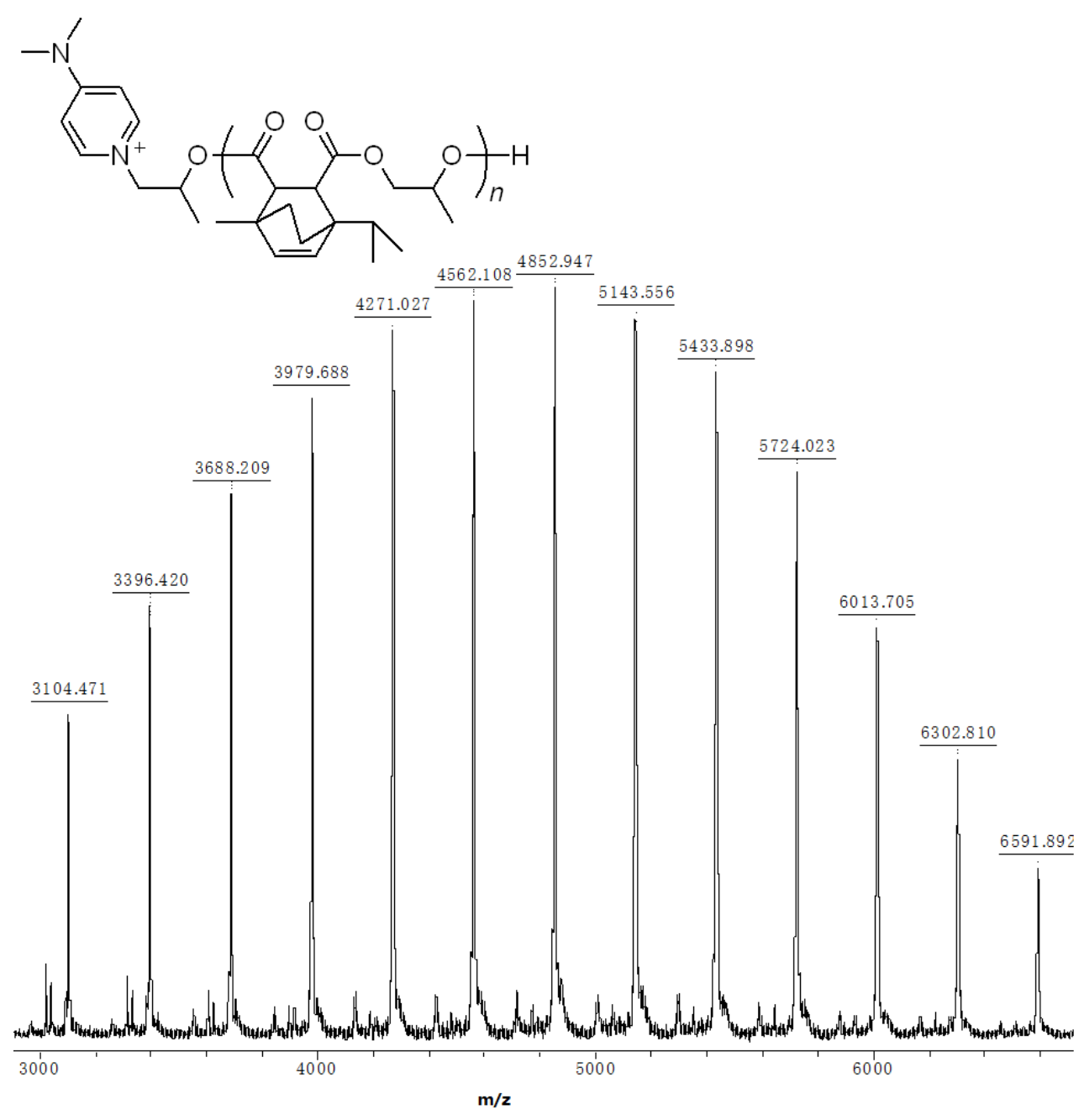

Figure S6 MALDI-TOF MS spectrum of the $\mathbf{2 a / 1 \mathbf { b }}$ copolymer (table 1, entry 9) $\left(M_{\mathrm{n}} 3000-7000\right)$.

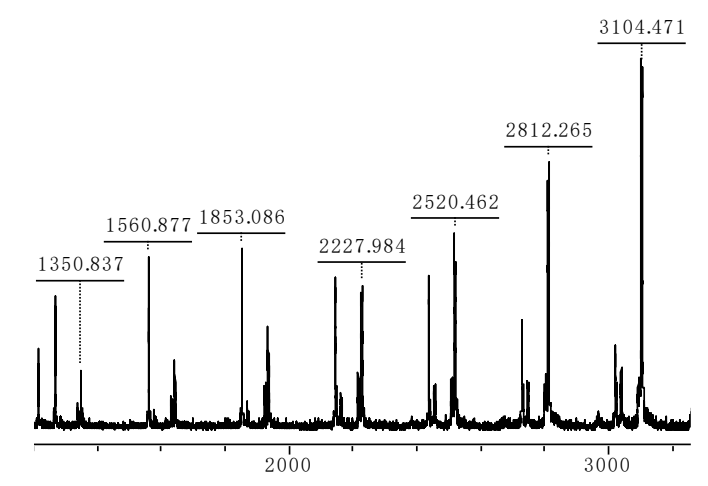

Figure S7 MALDI-TOF MS spectrum of the $\mathbf{2 a / 1 \mathbf { b }}$ copolymer (table 1, entry 9) $\left(M_{\mathrm{n}}<3000\right)$. 


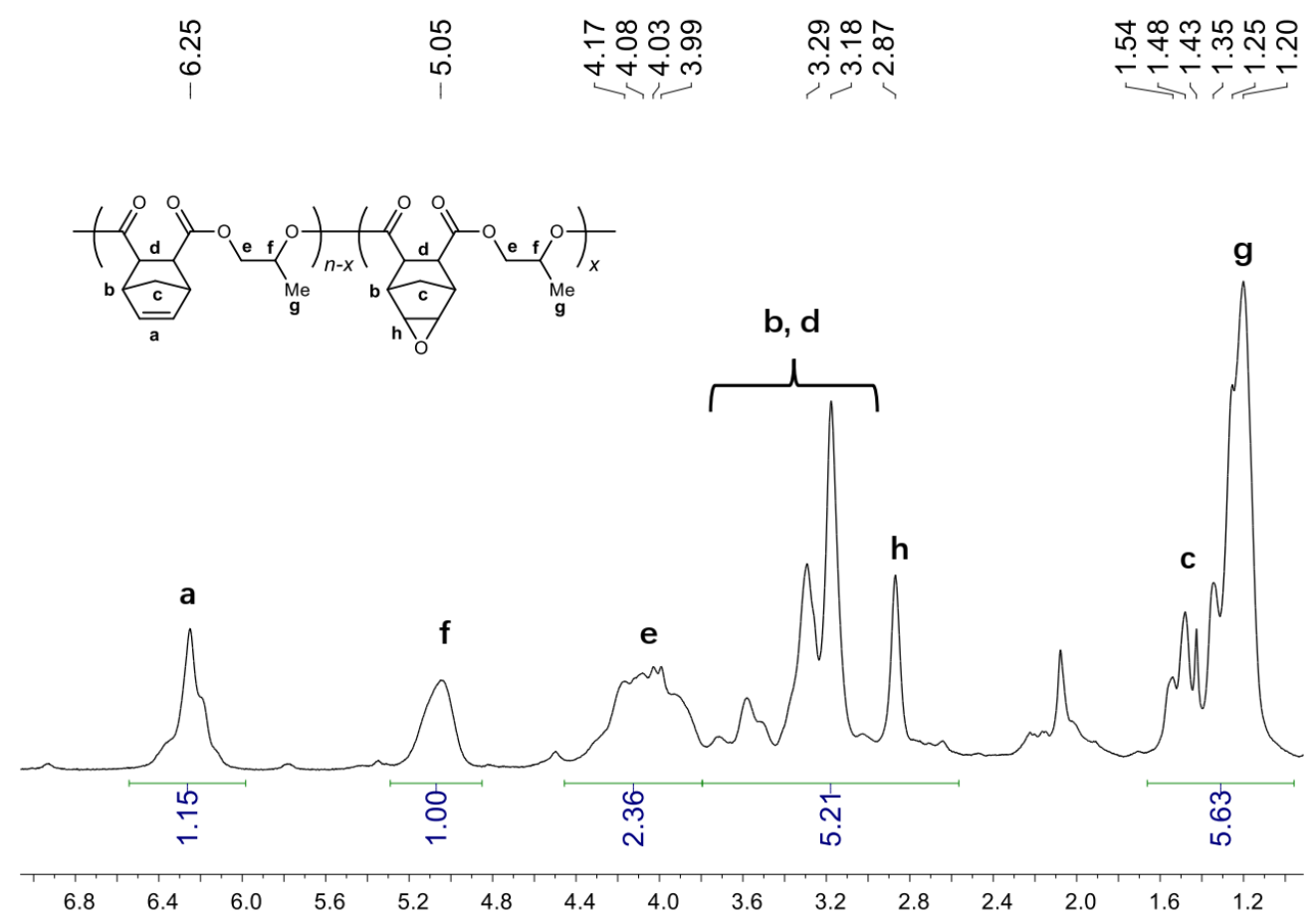

Figure S8 ${ }^{1} \mathrm{H}$ NMR spectrum of epoxy-functionalized 1a/1b copolymer (EP1) (Table $\mathrm{S} 1$, entry 1) (containing small amounts of hexanes and acetone) $\left(400 \mathrm{MHz}, \mathrm{CDCl}_{3}\right.$, $\left.25^{\circ} \mathrm{C}\right)$. Conversion $=\left(1-\mathrm{I}_{\mathrm{a}} /\left(2 * \mathrm{I}_{\mathrm{f}}\right)\right) * 100 \%=43 \%$.

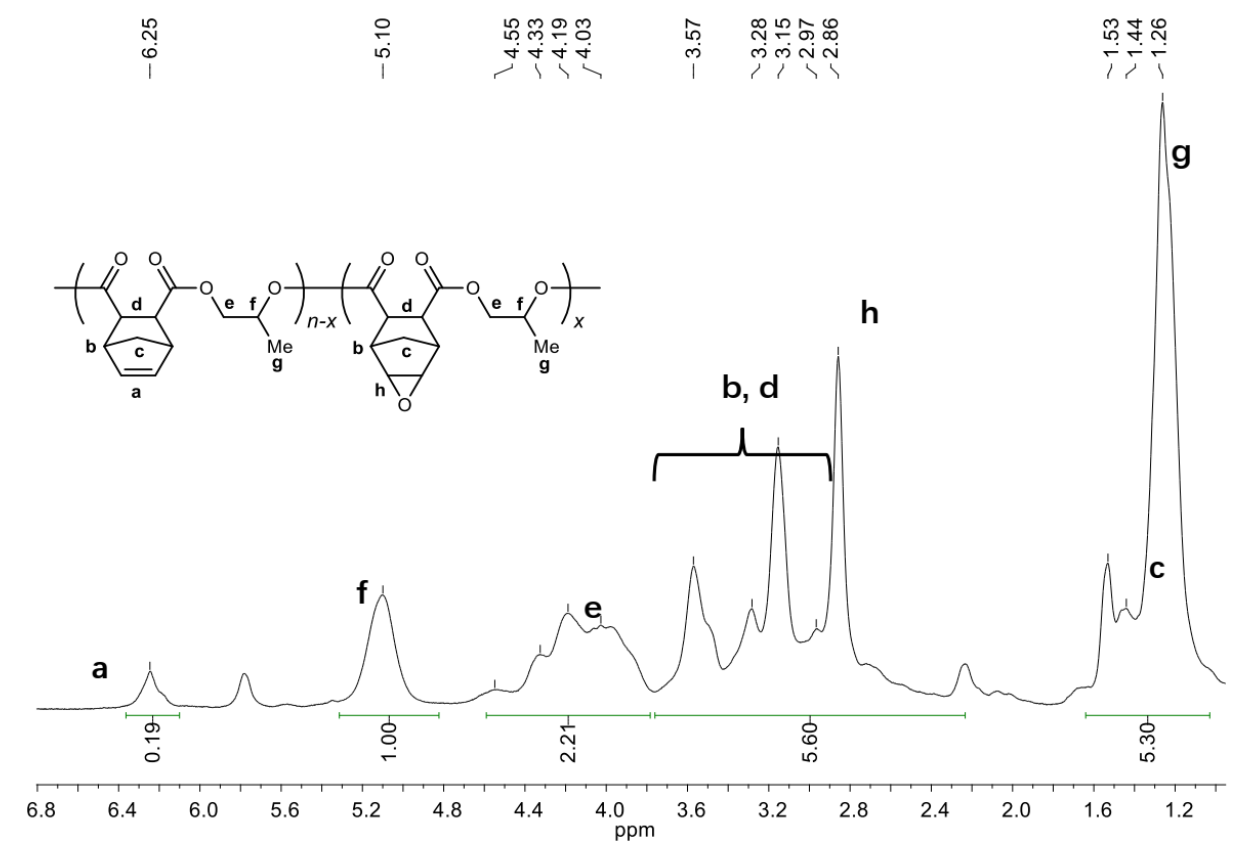

Figure S9 ${ }^{1} \mathrm{H}$ NMR spectrum of epoxy-functionalized 1a/1b copolymer (EP2) (Table $\mathrm{S} 1$, entry 8 ) (containing small amounts of hexanes) $\left(400 \mathrm{MHz}, \mathrm{CDCl}_{3}, 25^{\circ} \mathrm{C}\right)$. Conversion $=\left(1-\mathrm{I}_{\mathrm{a}} /\left(2 * \mathrm{I}_{\mathrm{f}}\right)\right) * 100 \%=91 \%$. 

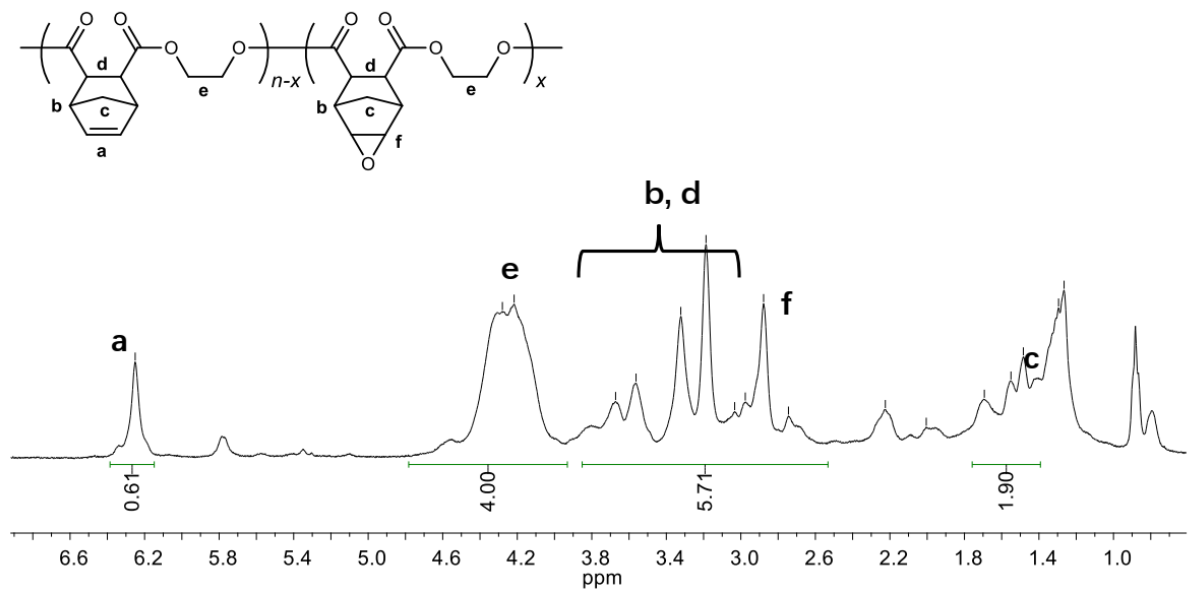

Figure S10 ${ }^{1} \mathrm{H}$ NMR spectrum of epoxy-functionalized $\mathbf{1 a} / \mathbf{2} \mathbf{b}$ copolymer (EP3) (Table S1, entry 9) (containing hexanes) $\left(400 \mathrm{MHz}, \mathrm{CDCl}_{3}, 25^{\circ} \mathrm{C}\right)$. Conversion $=\left(1-\mathrm{I}_{\mathrm{a}}\right.$ $\left./\left(0.5 * \mathrm{I}_{\mathrm{e}}\right)\right) * 100 \%=70 \%$.

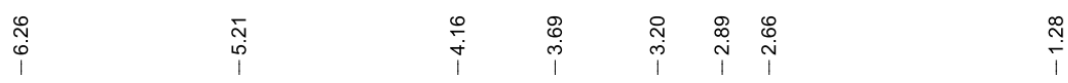

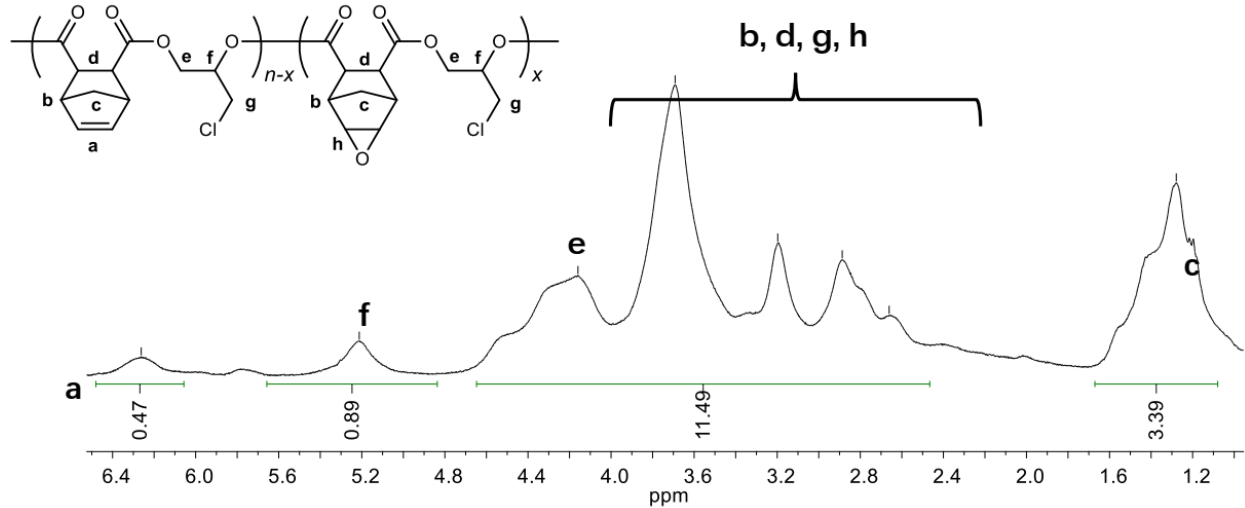

Figure S11 ${ }^{1} \mathrm{H}$ NMR spectrum of epoxy-functionalized $\mathbf{1 a} / \mathbf{3 b}$ copolymer $(\mathbf{E P 4})$ (Table S1, entry 10) (containing hexanes) $\left(400 \mathrm{MHz}, \mathrm{CDCl}_{3}, 25^{\circ} \mathrm{C}\right)$. Conversion $=(1-$ $\left.\mathrm{I}_{\mathrm{a}} /\left(2 * \mathrm{I}_{\mathrm{f}}\right)\right) * 100 \%=75 \%$. 


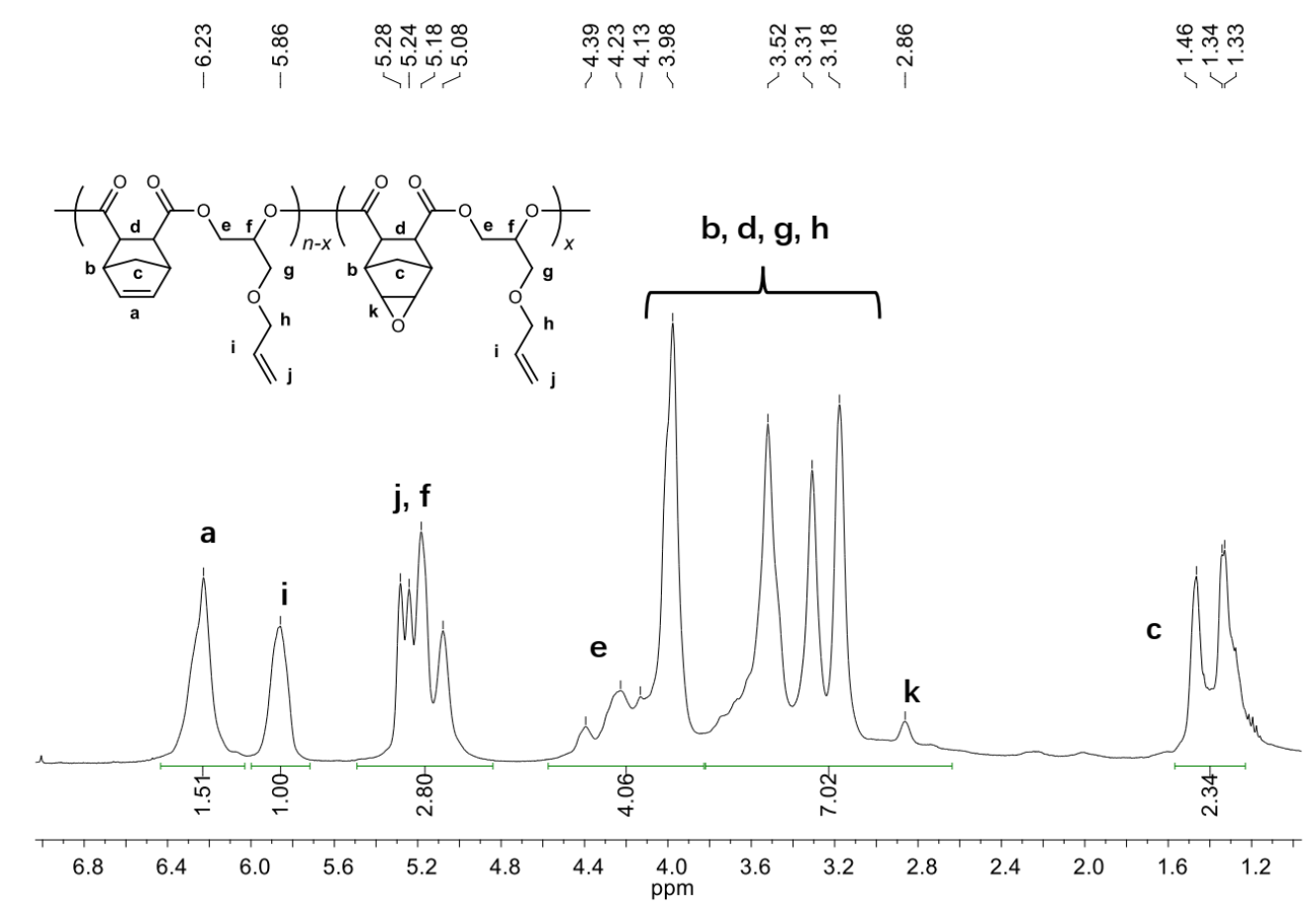

Figure S12 ${ }^{1}$ H NMR spectrum of epoxy-functionalized 1a/4b copolymer (EP5) (Table S1, entry 11) (containing hexanes) $\left(400 \mathrm{MHz}, \mathrm{CDCl}_{3}, 25^{\circ} \mathrm{C}\right)$. Conversion $=(1$ $\left.\mathrm{I}_{\mathrm{a}} /\left(2 * \mathrm{I}_{\mathrm{i}}\right)\right) * 100 \%=25 \%$.

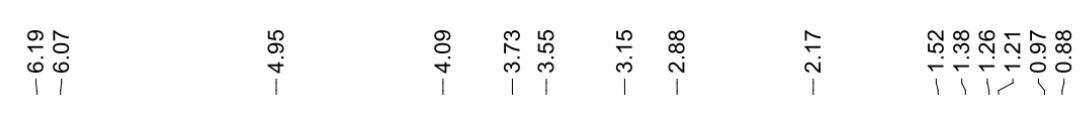

$$
\text { b, c, e, i }
$$
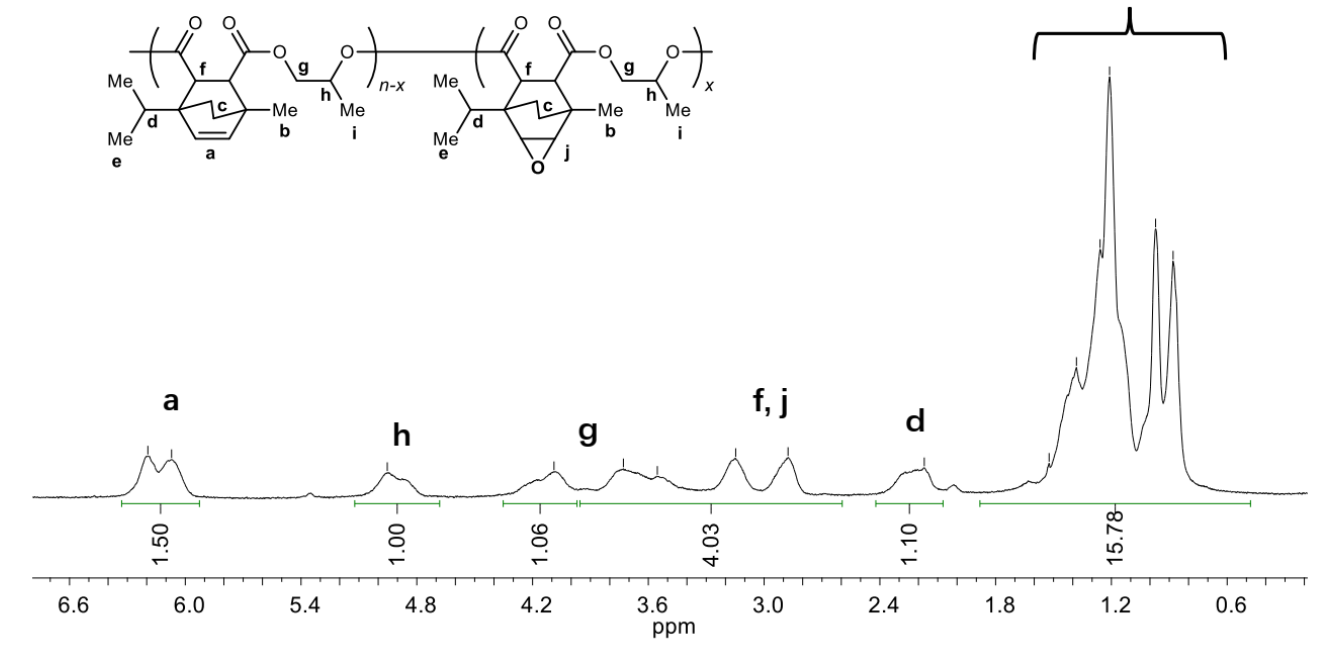

Figure S13 ${ }^{1} \mathrm{H}$ NMR spectrum of epoxy-functionalized 2a/1b copolymer (EP6) (Table S1, entry 12) $\left(400 \mathrm{MHz}, \mathrm{CDCl}_{3}, 25^{\circ} \mathrm{C}\right)$. Conversion $=\left(1-\mathrm{I}_{\mathrm{a}} /\left(2 * \mathrm{I}_{\mathrm{h}}\right)\right) * 100 \%=$ $25 \%$. 


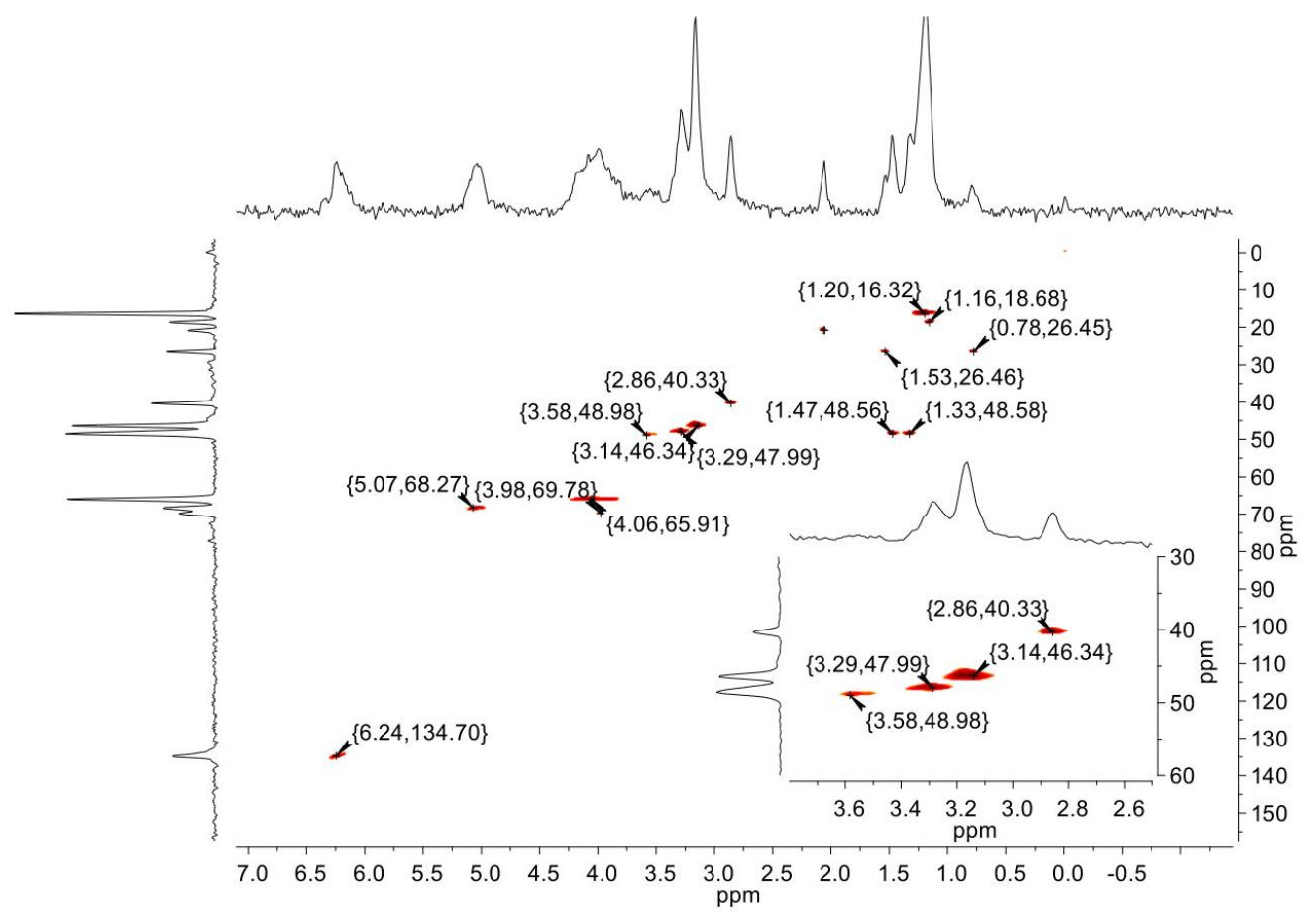

Figure S14 2D HSQC NMR spectrum of epoxy-functionalized 1a/1b copolymer (EP1) (Table S1, entry 1) (epoxy group: 2.86 ppm and 40.33 ppm).

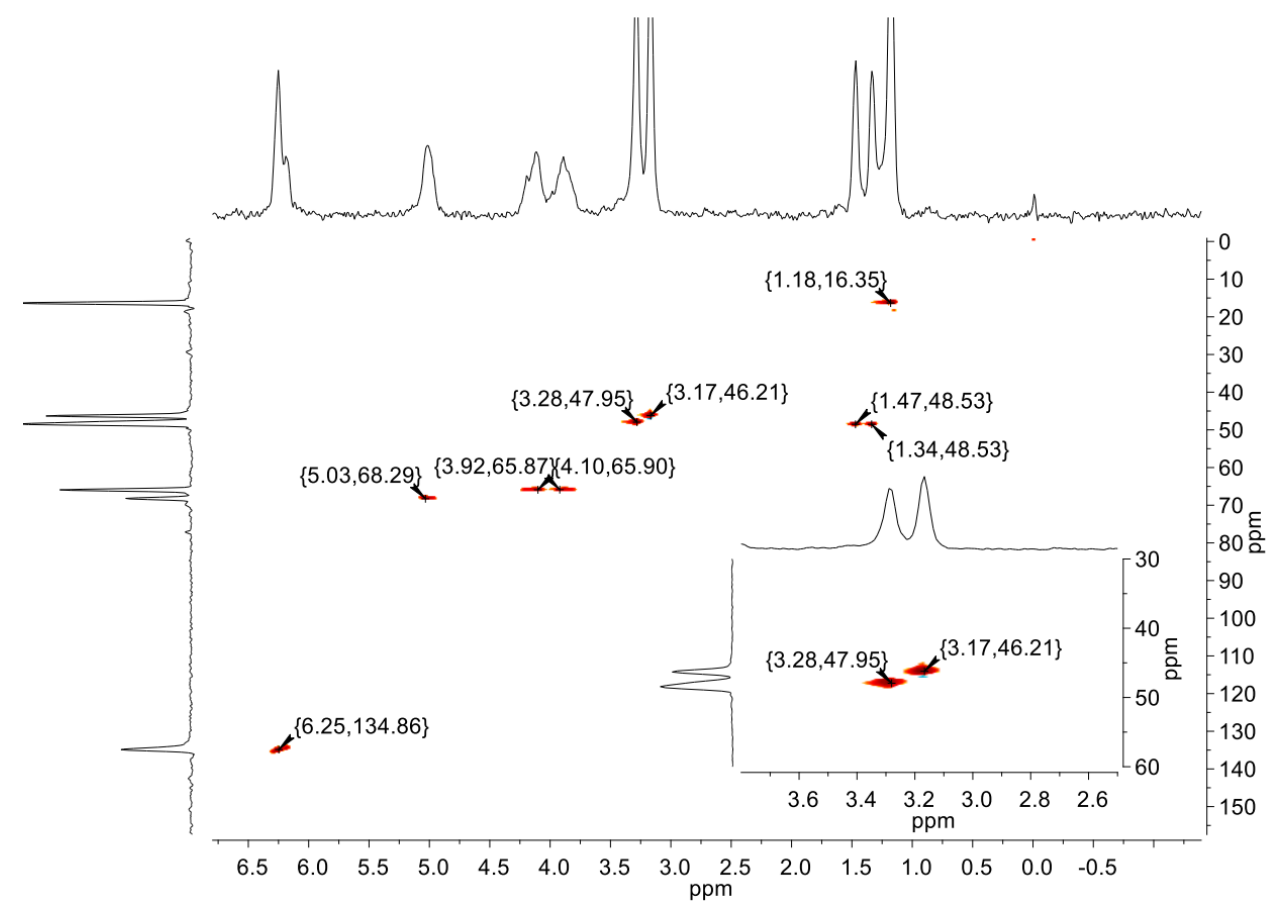

Figure S15 2D HSQC NMR spectrum of $\mathbf{1 a} / \mathbf{1} \mathbf{b}$ copolymer (Table 1, entry 1). 

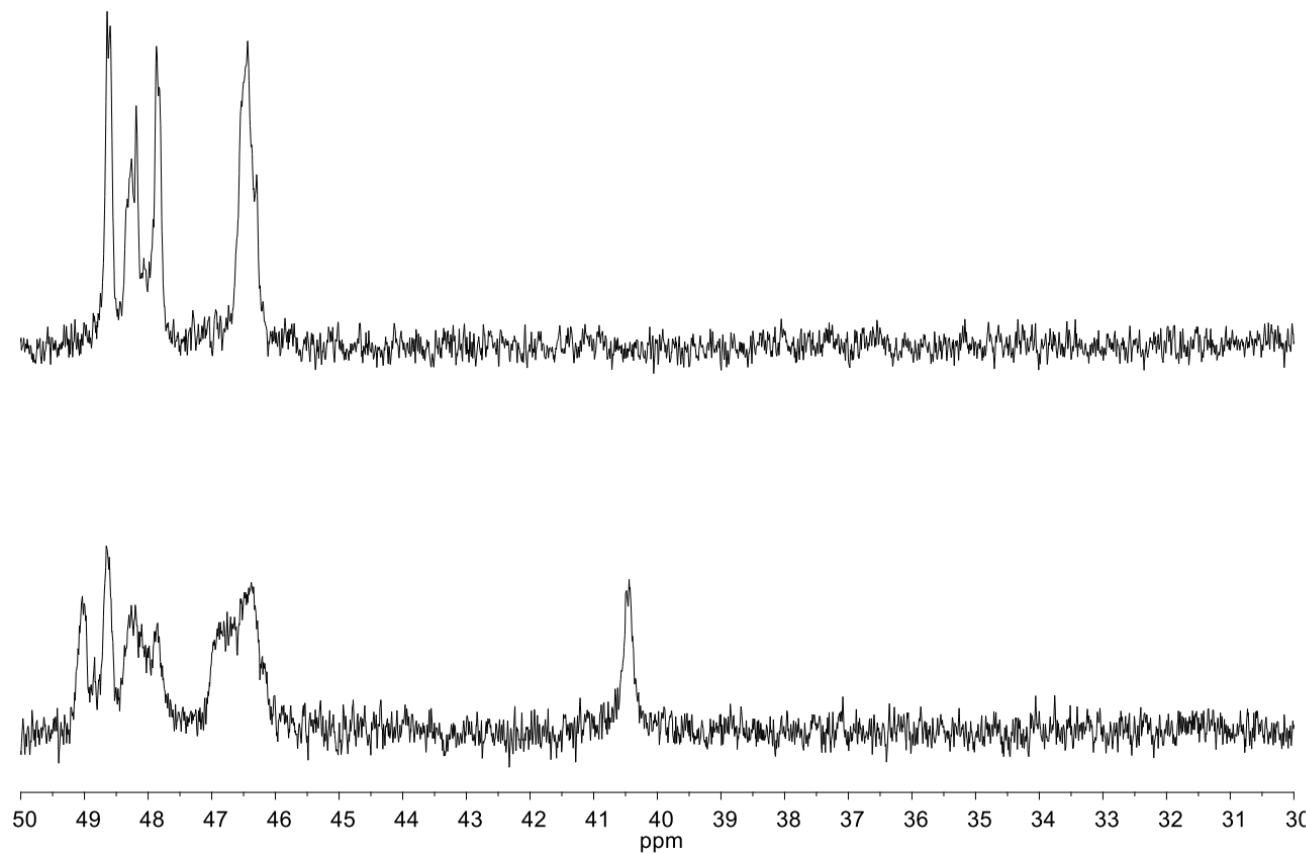

Figure S16 ${ }^{13} \mathrm{C}$ NMR spectra (30-50 ppm) of 1a/1b copolymer (top) (Table 1, entry 1) and epoxy-functionalized 1a/1b copolymer (EP1) (bottom) (Table S1, entry 1) (the characteristic peak of the epoxy group: $40.44 \mathrm{ppm})\left(100 \mathrm{MHz}, \mathrm{CDCl}_{3}, 25{ }^{\circ} \mathrm{C}\right)$.

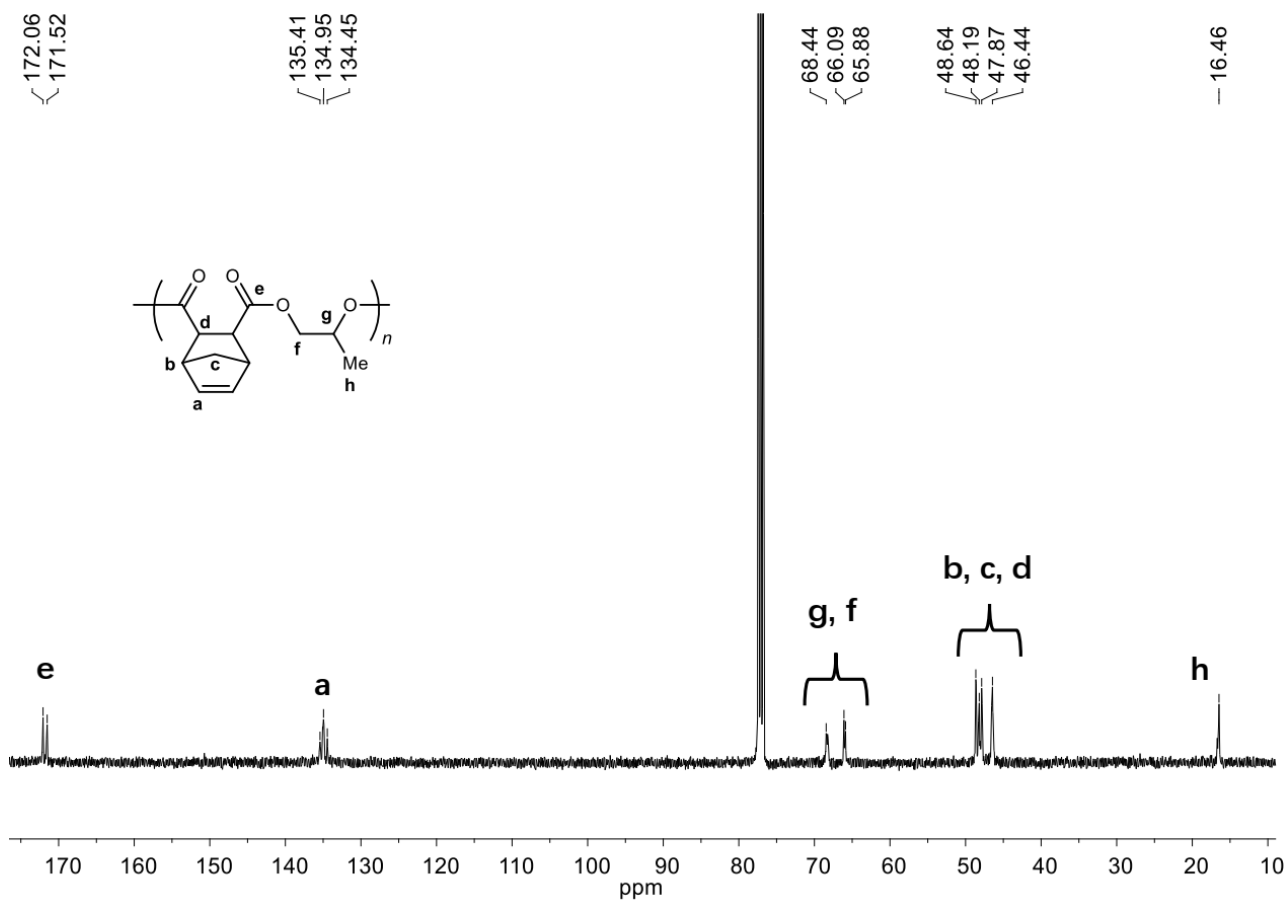

Figure $\mathbf{S 1 7}{ }^{13} \mathrm{C}$ NMR spectrum of $\mathbf{1 a} / \mathbf{1 b}$ copolymer (Table 1, entry 1) (100MHz, $\left.\mathrm{CDCl}_{3}, 25^{\circ} \mathrm{C}\right)$. 

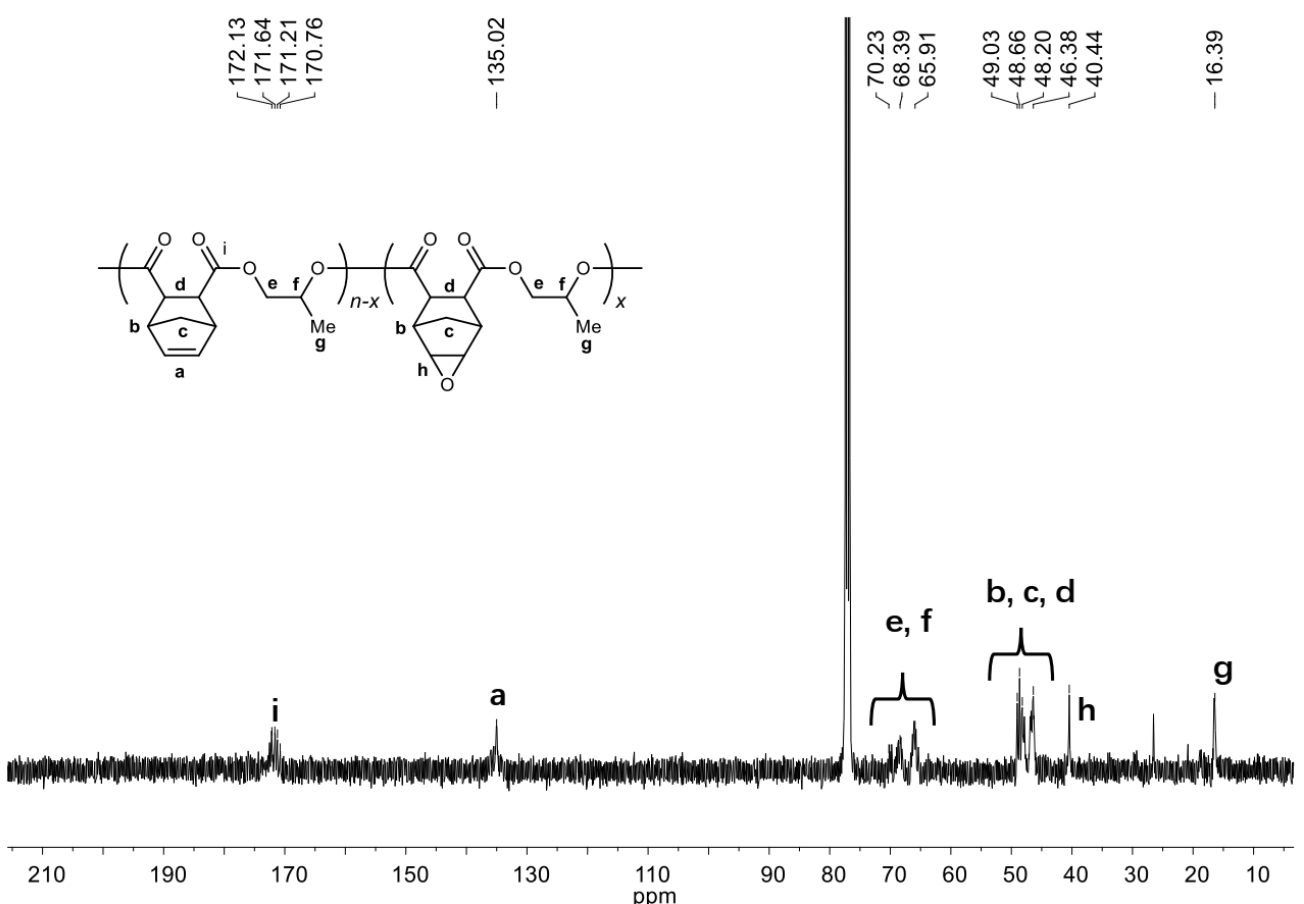

Figure S18 ${ }^{13} \mathrm{C}$ NMR spectrum of epoxy-functionalized 1a/1b copolymer (EP1) (Table S1, entry 1) $\left(100 \mathrm{MHz}, \mathrm{CDCl}_{3}, 25^{\circ} \mathrm{C}\right)$.

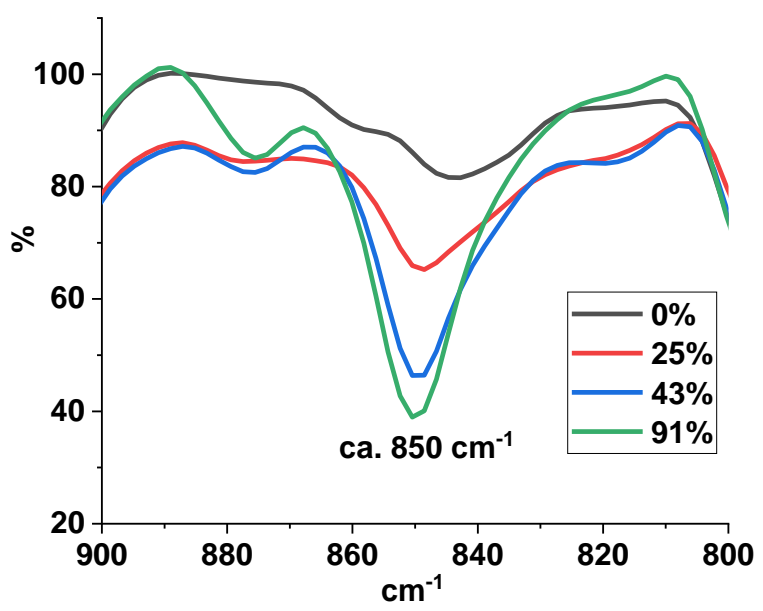

Figure S19 FT-IR spectra $\left(800-900 \mathrm{~cm}^{-1}\right)$ of epoxy-functionalized $\mathbf{1 a} / \mathbf{1 b}$ copolymers (Black: conv. $=0 \%$, Table 1 , entry 5 ; Red: conv. $=25 \%$, Table S1, entry 2 ; Blue: conv. $=43 \%(\mathbf{E P 1})$, Table S1, entry 1; Green: conv. $=91 \%(\mathbf{E P 2})$, Table S1, entry 8$)$ (asymmetric epoxide ring stretching deformation vibration: ca. $850 \mathrm{~cm}^{-1}$ ) (in $\mathrm{KBr}$, $\left.25^{\circ} \mathrm{C}\right)$. 


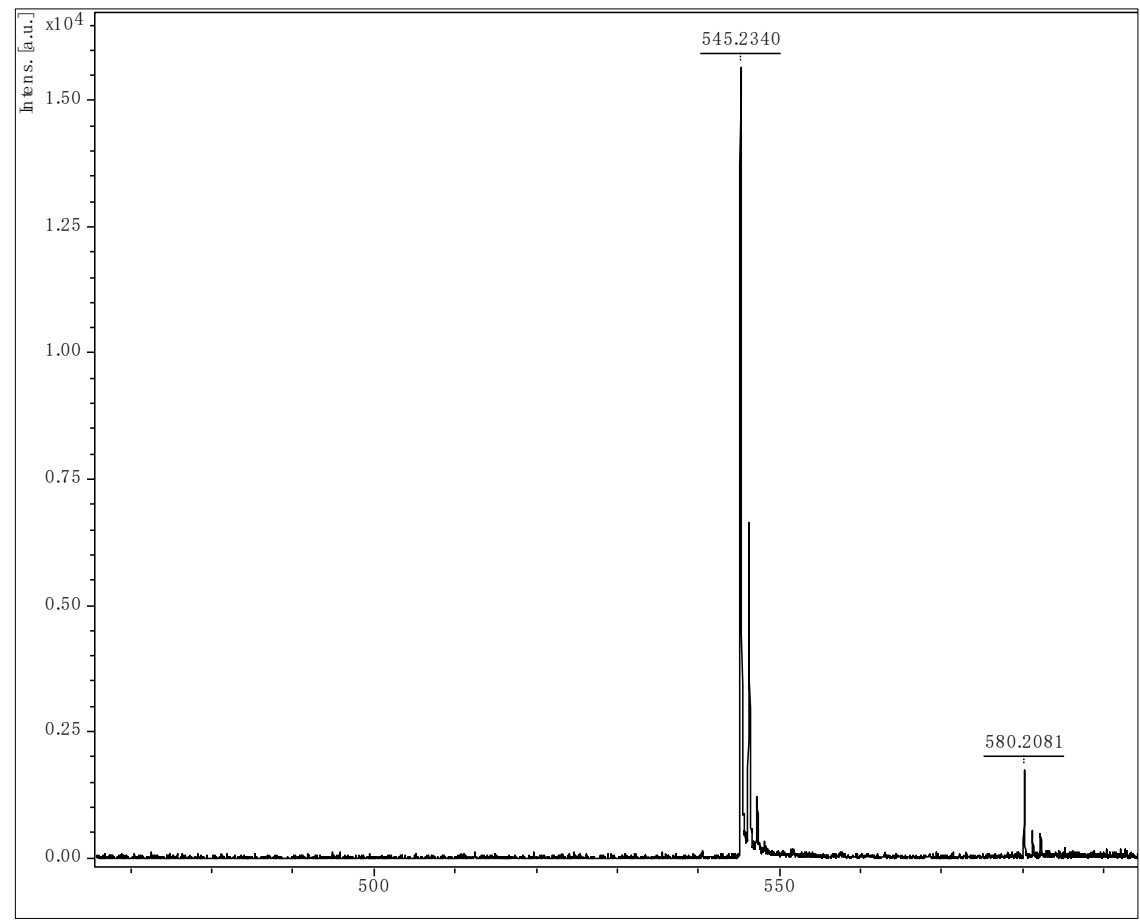

Figure S20 MALDI-TOF MS spectrum of En-Mn (for comparison).

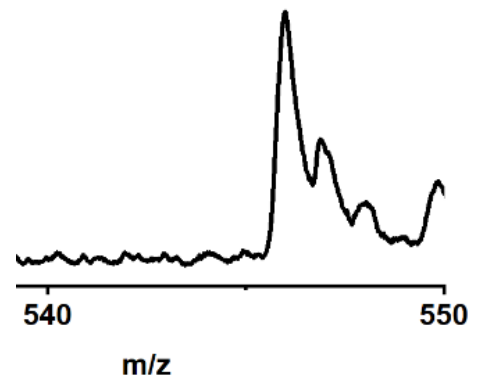

Figure S21 MALDI-TOF MS spectrum of EP2 without purification (m/z: 540$550)$.

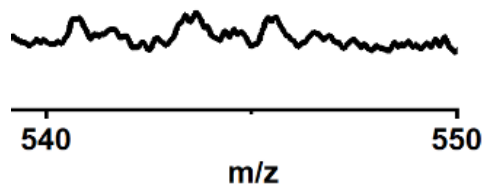

Figure S22 MALDI-TOF MS spectrum of EP2 precipitated from hexanes for two times (m/z: 540-550). 


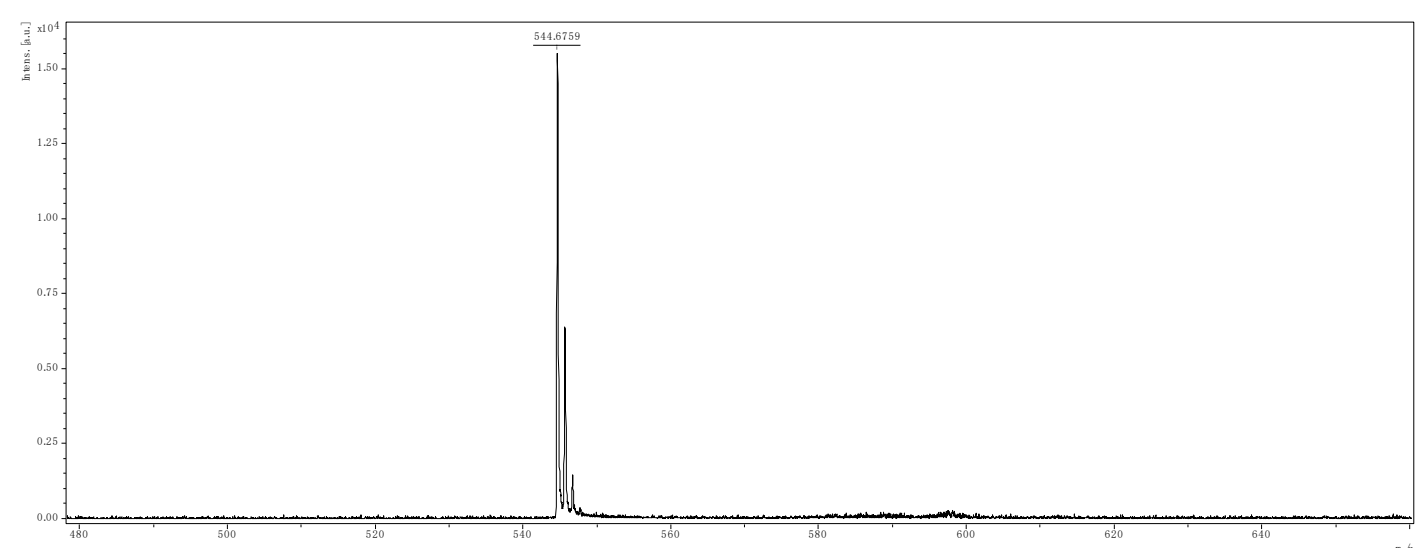

Figure S23 MALDI-TOF MS spectrum of the dichloromethane solution of En-Mn $(0.05 \mathrm{M})$ stirred with the aqueous solution of sodium hypochlorite for $2 \mathrm{~d}$ at $25{ }^{\circ} \mathrm{C}$.

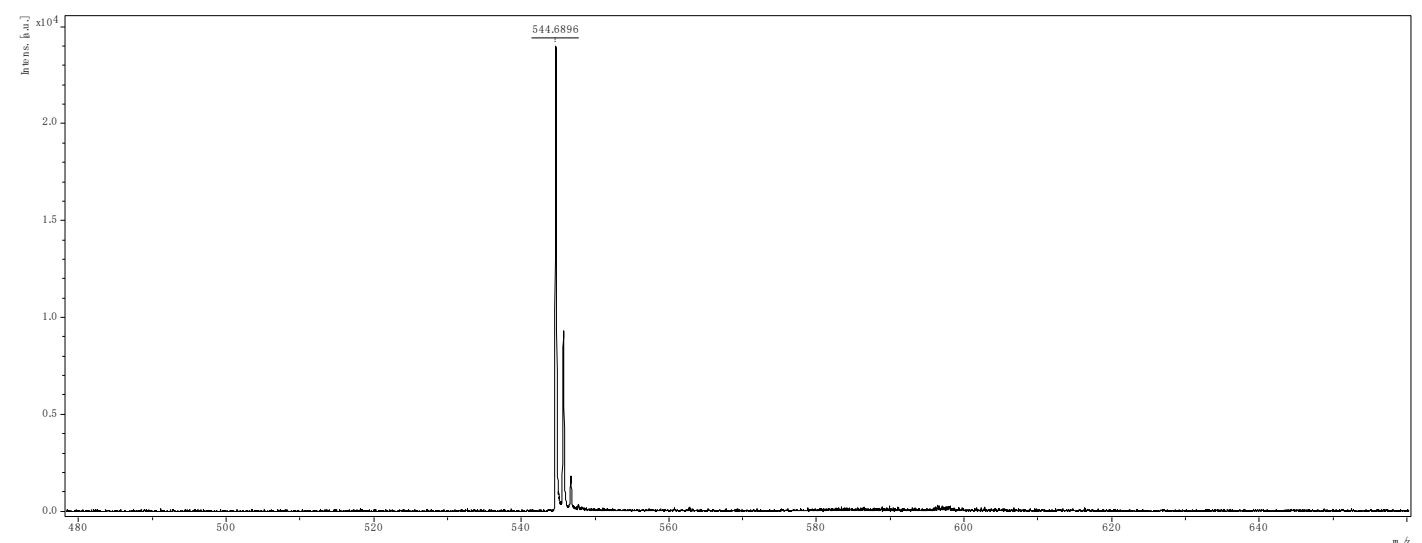

Figure S24 MALDI-TOF MS spectrum of the dichloromethane solution of En-Mn $(0.05 \mathrm{M})$ and norbornene (100 equiv.) stirred with the aqueous solution of sodium hypochlorite for $2 \mathrm{~d}$ at $25^{\circ} \mathrm{C}$. 


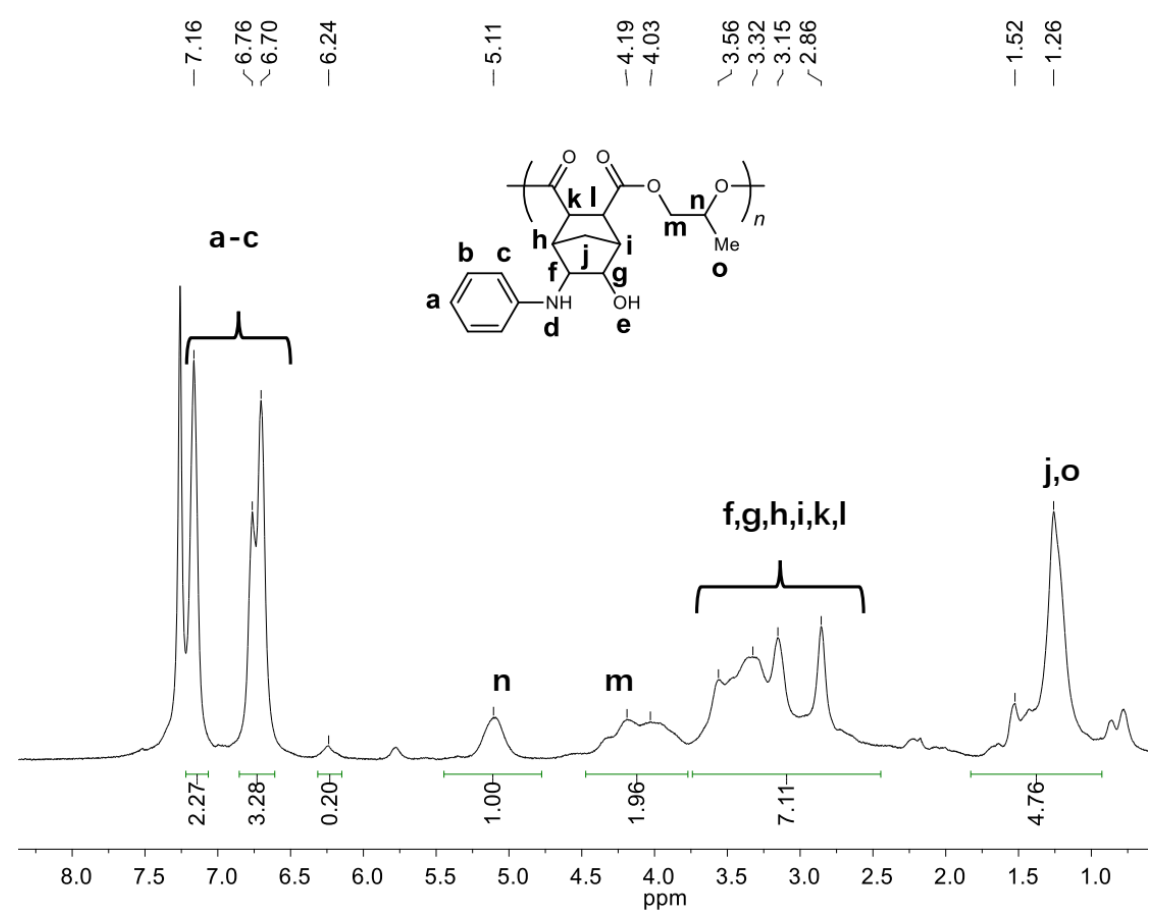

Figure S25 ${ }^{1} \mathrm{H}$ NMR spectrum of the arylamine-functionalized polyester (A1) (containing hexanes) $\left(400 \mathrm{MHz}, \mathrm{CDCl}_{3}, 25^{\circ} \mathrm{C}\right)$.

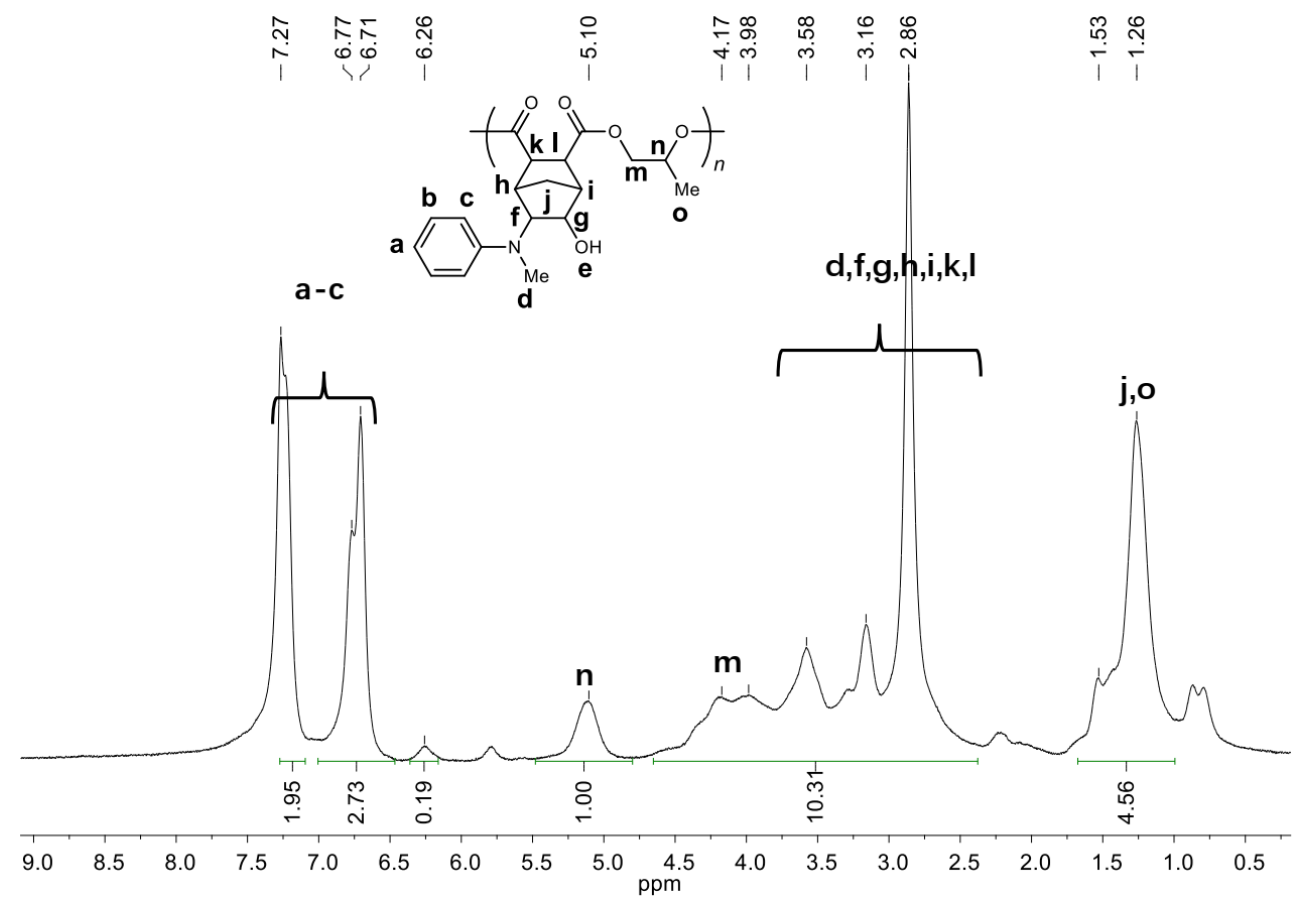

Figure S26 ${ }^{1} \mathrm{H}$ NMR spectrum of the arylamine-functionalized polyester (A2) (containing hexanes) $\left(400 \mathrm{MHz}, \mathrm{CDCl}_{3}, 25^{\circ} \mathrm{C}\right.$ ). 

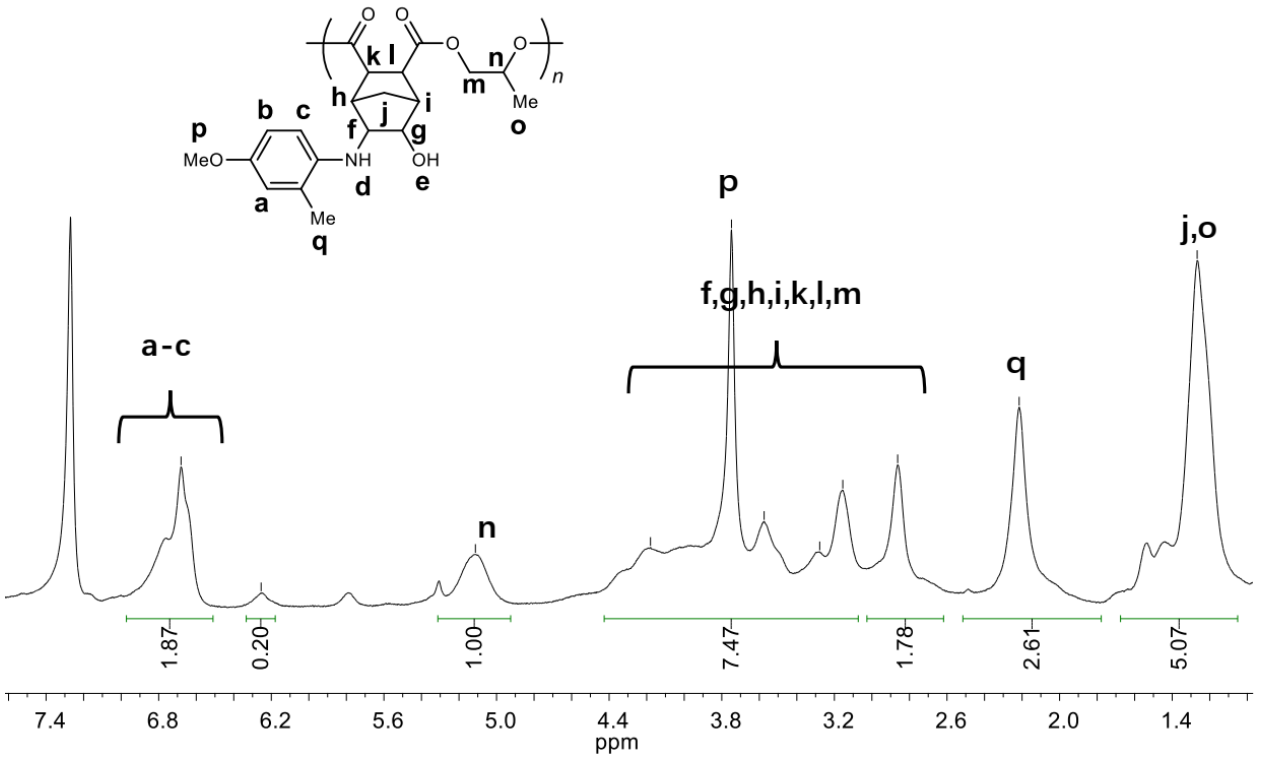

Figure S27 ${ }^{1} \mathrm{H}$ NMR spectrum of the arylamine-functionalized polyester (A3) (containing hexanes) $\left(400 \mathrm{MHz}, \mathrm{CDCl}_{3}, 25^{\circ} \mathrm{C}\right)$.

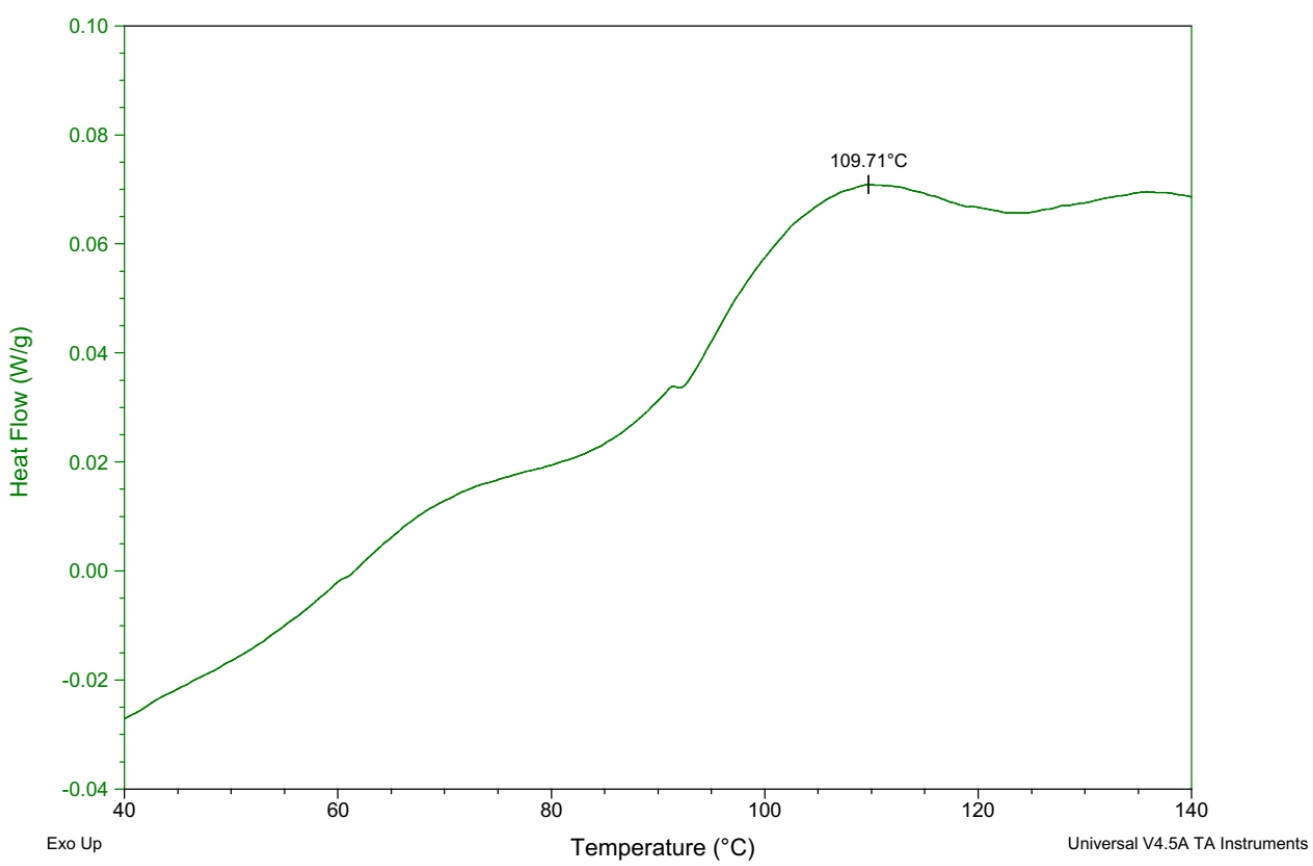

Figure S28 DSC curve of A1/DGEBA mixture (weight ratio $=1 / 1)\left(1^{\circ} \mathrm{C} / \mathrm{min}\right)$. 


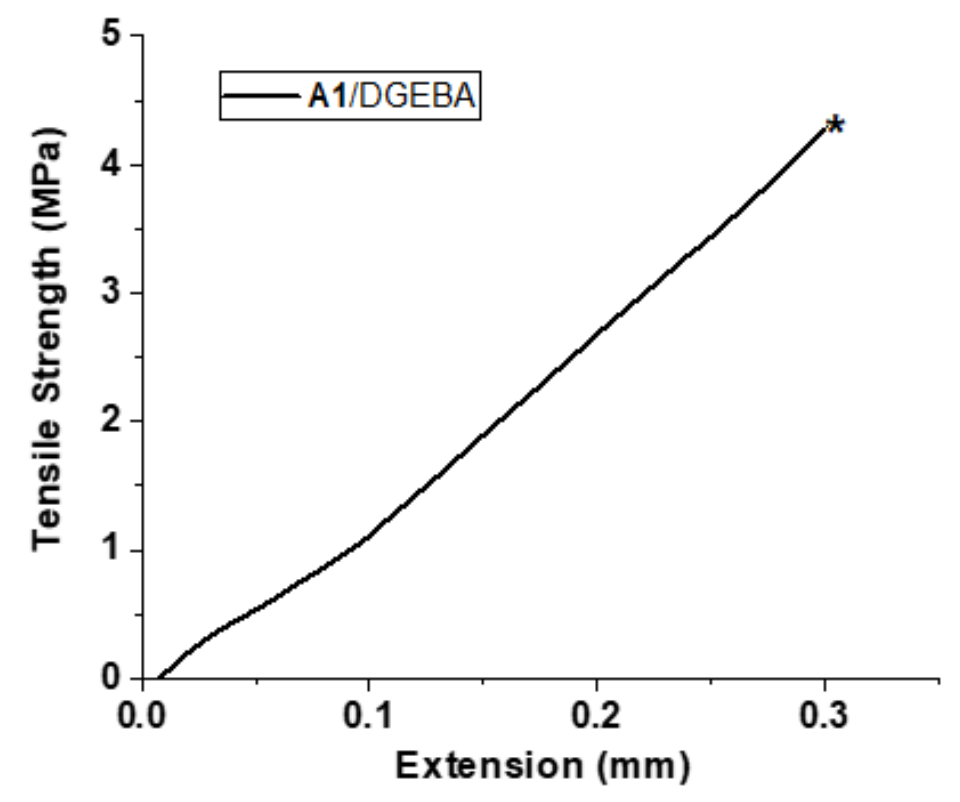

Figure S29 Representative stress-strain curves of cured A1/DGEBA (molar ratio: arylamine/epoxy $=1 / 1)$. At least three parallel experiments for each epoxy resin were conducted, and the average results were reported.

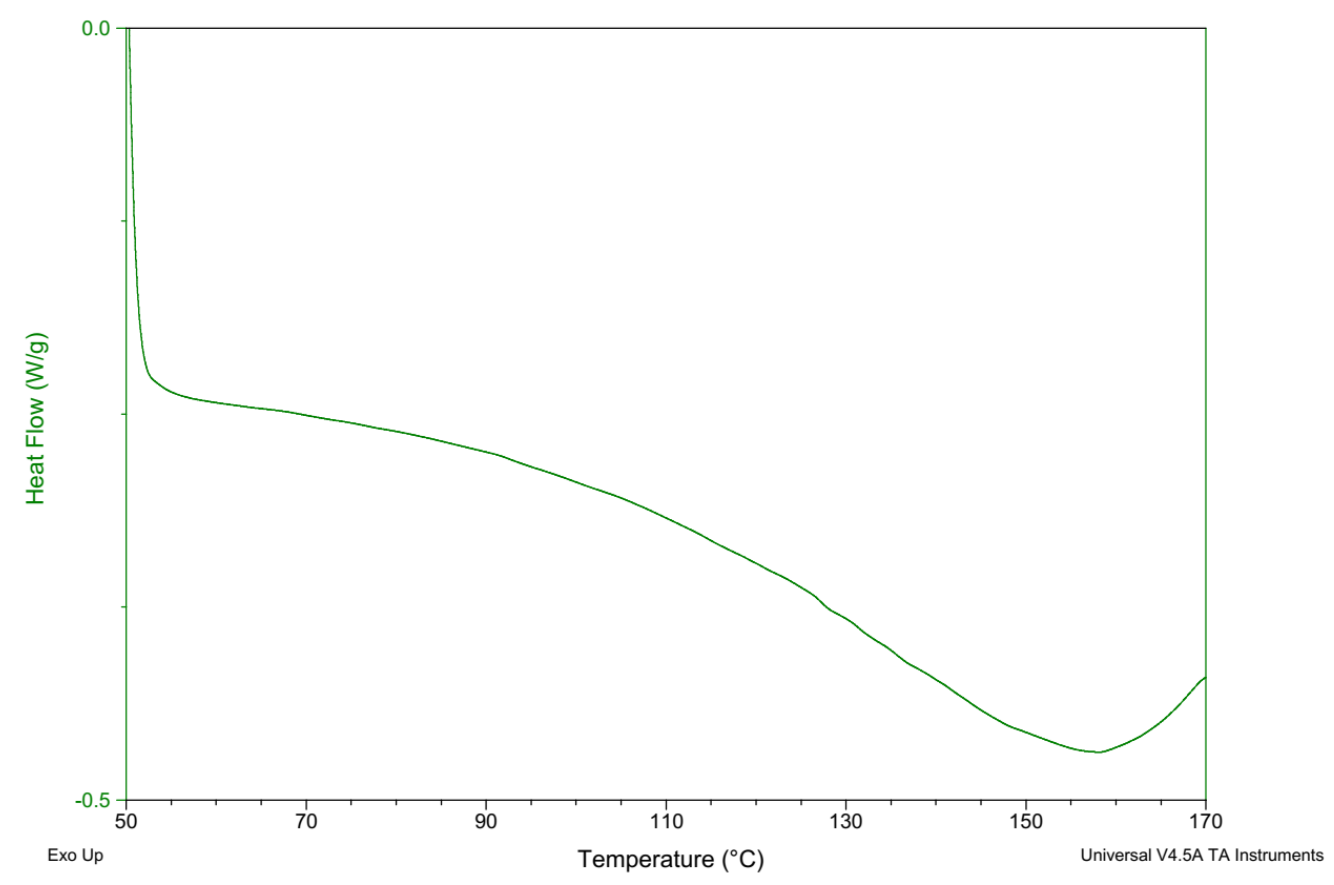

Figure S30 DSC curve of the methyl nadic anhydride/DGEBA mixture (molar ratio $=$ 2/1) $\left(1^{\circ} \mathrm{C} / \mathrm{min}\right)$. 


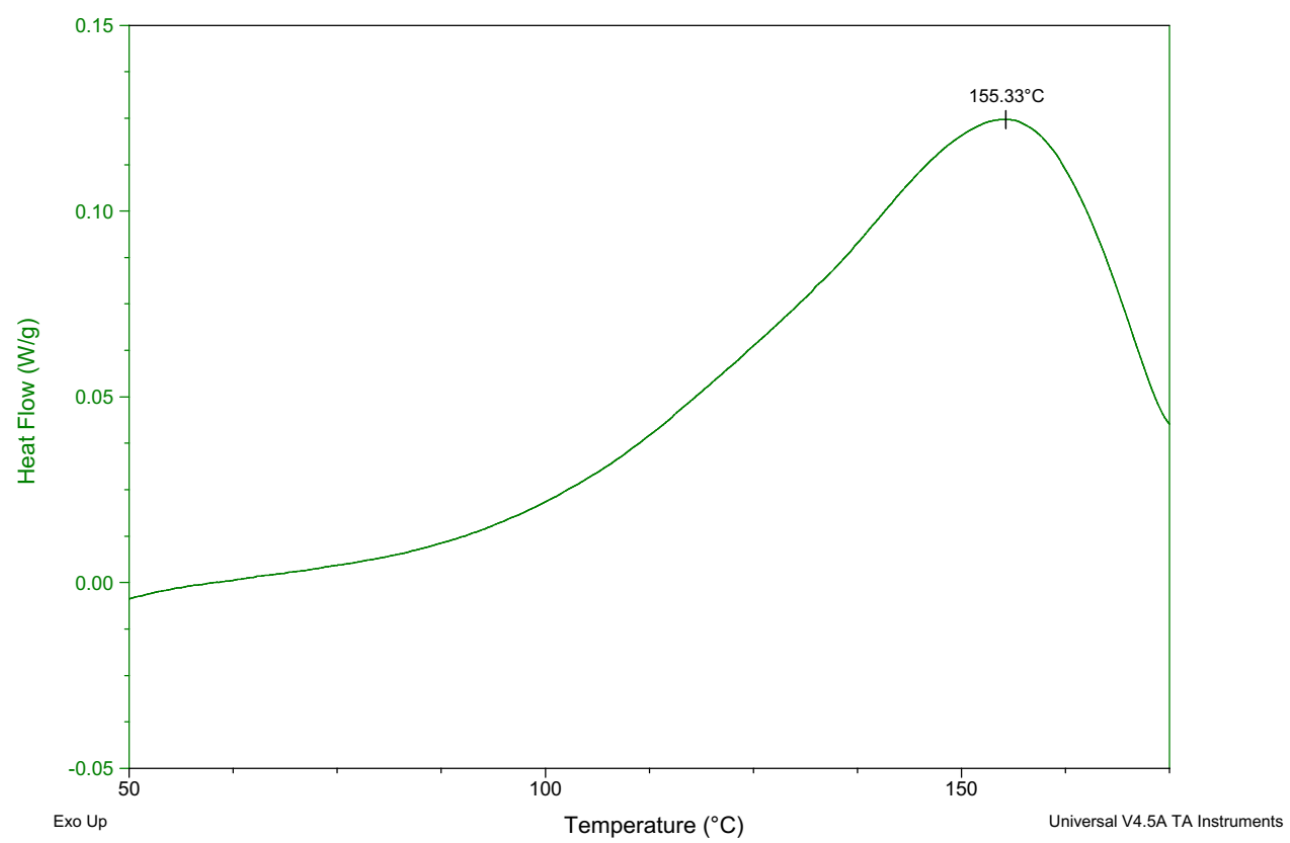

Figure S31 DSC curve of the methyl nadic anhydride/DGEBA mixture (molar ratio = $2 / 1$ ) containing $1 \mathrm{~mol} \%$ of En-Mn (based on methyl nadic anhydride) $\left(1^{\circ} \mathrm{C} / \mathrm{min}\right)$.

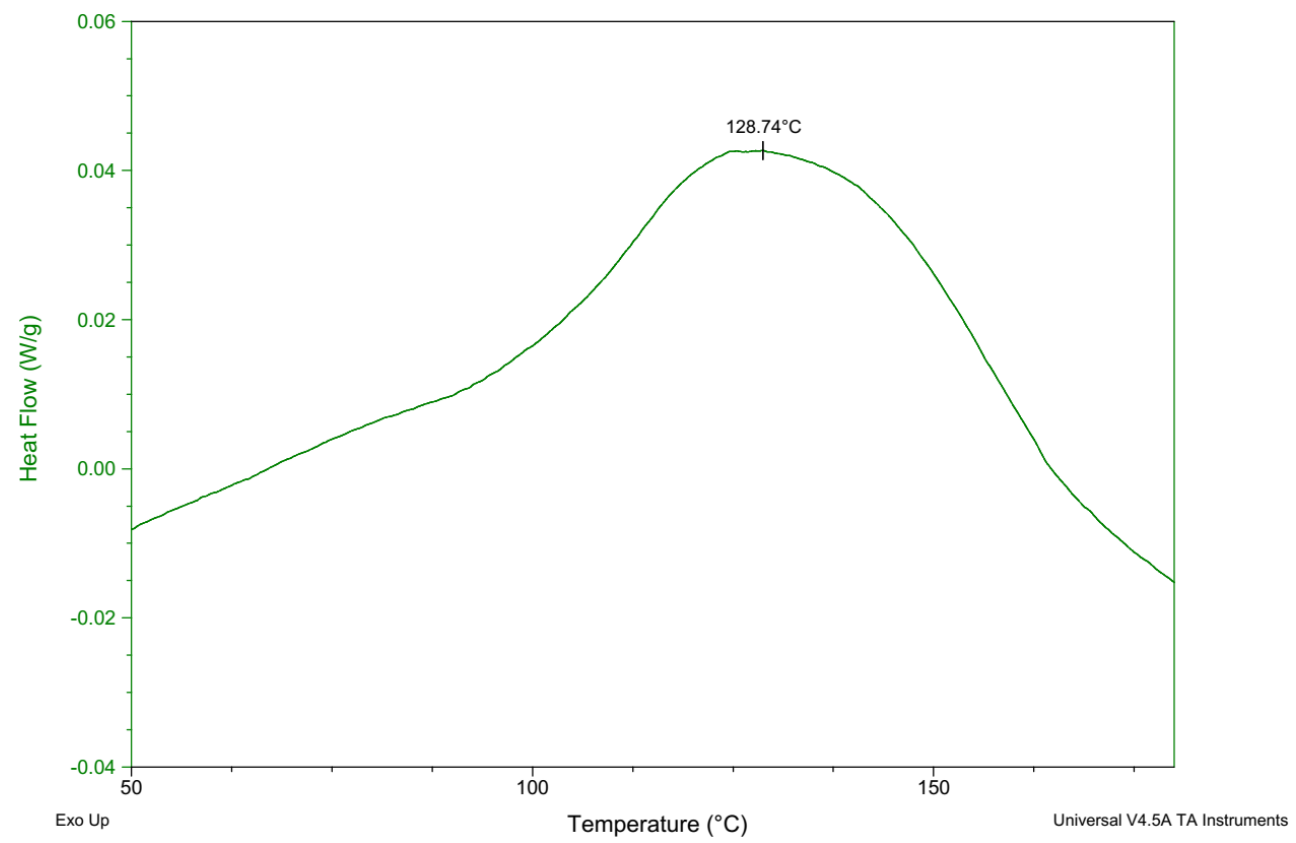

Figure S32 DSC curve of the methyl nadic anhydride/EP1 mixture (weight ratio = 1/1) containing $2 \mathrm{~mol} \%$ of Mn-salen catalyst (based on the nadic anhydride repeat unit) $\left(1^{\circ} \mathrm{C} / \mathrm{min}\right)$. 


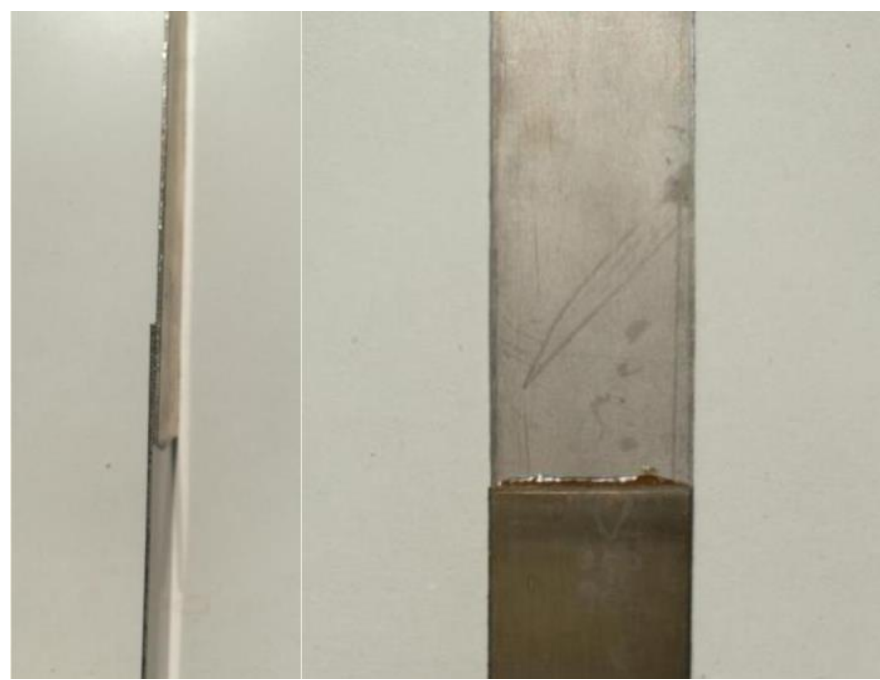

Figure S33 Representative photograph of the samples for lap shear test.

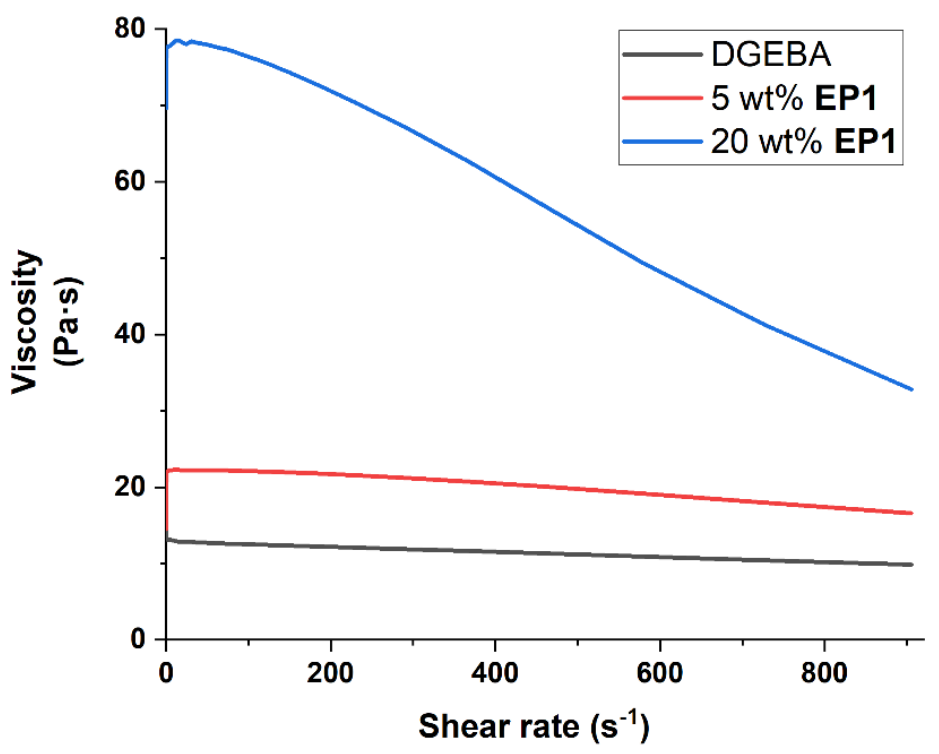

Figure S34 Viscosities of DGEBA (black) and the mixture of DGEBA and EP1 (red: $5 \mathrm{wt} \%$ EP1; blue $20 \mathrm{wt} \%$ EP1) at $17^{\circ} \mathrm{C}$ (shearing rate: $10^{-3} \sim 10^{3} \mathrm{~s}^{-1}$ ). 


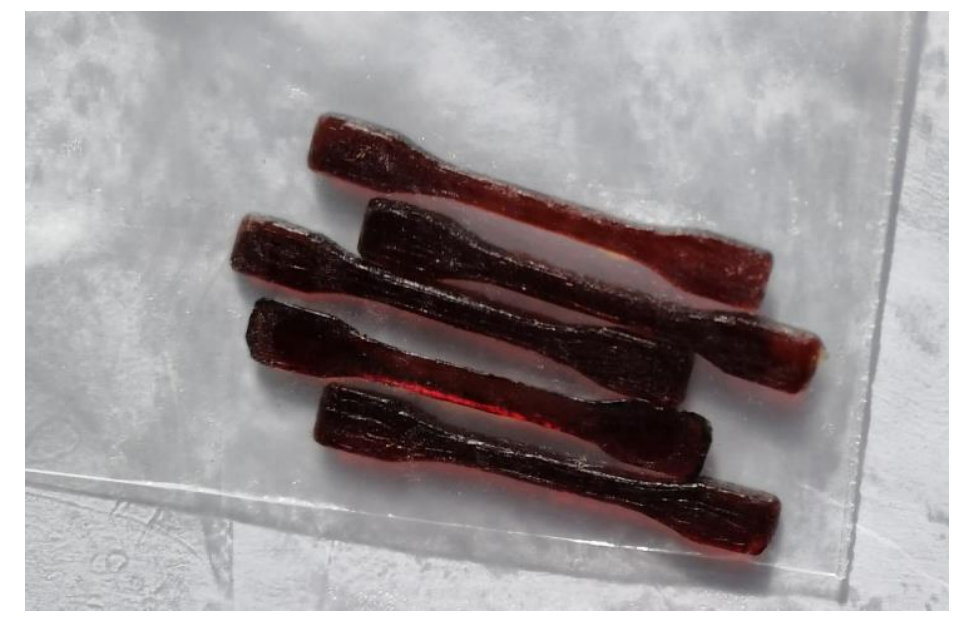

Figure S35 Representative photograph of the dog-bone shape tensile bars.

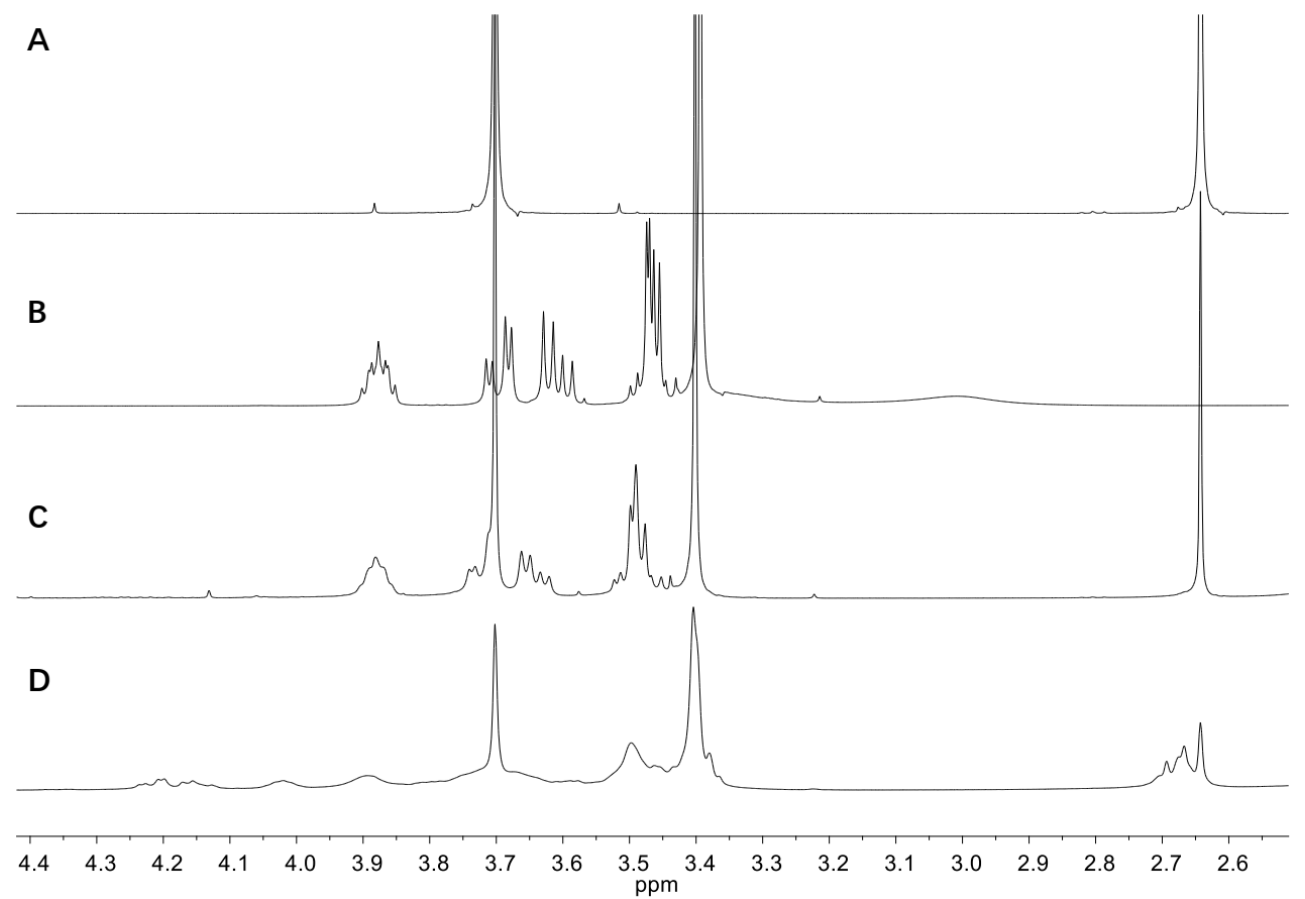

Figure S36 ${ }^{1} \mathrm{H}$ NMR spectra (400MHz, $\mathrm{CDCl}_{3}, 25^{\circ} \mathrm{C}$ ): (A) Dimethyl succinate. (B) 3-Methoxy-1,2-propanediol. (C) The mixture of dimethyl succinate and 3-methoxy1,2-propanediol (3 equiv.) heated at $150^{\circ} \mathrm{C}$ for $3 \mathrm{~h}$. (D) The mixture of dimethyl succinate and 3-methoxy-1,2-propanediol (3 equiv.) heated at $150{ }^{\circ} \mathrm{C}$ for $3 \mathrm{~h}$ in the presence of $1 \mathrm{~mol} \% \mathbf{E n - M n}$. 


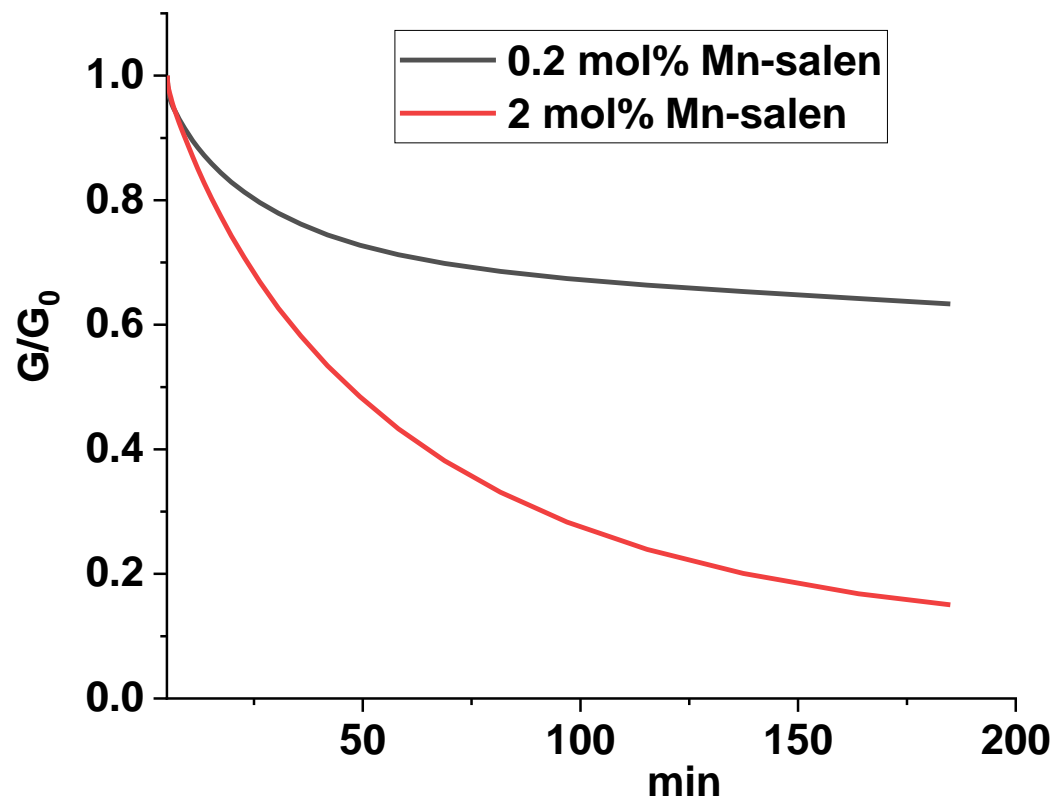

Figure S37 Normalized stress relaxation of cross-linked polymers with different Mn-salen contents at $190{ }^{\circ} \mathrm{C}$ (Black: molar ratio: $\mathrm{n}_{\text {epoxy group, }}$ EP2 $/ \mathrm{n}_{\mathrm{DGEBA}} / \mathrm{n}_{\mathrm{GA}} / \mathrm{n}_{\mathrm{TEG}}=$

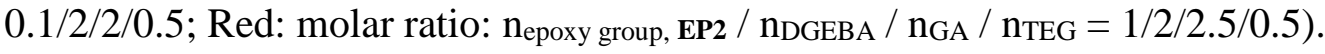

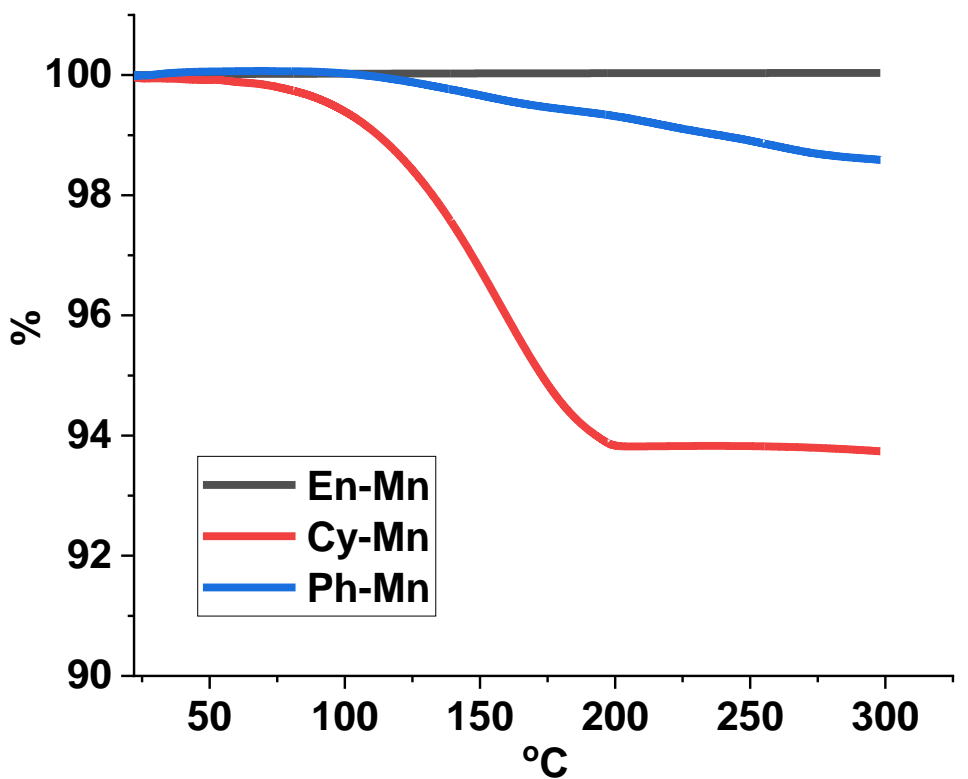

Figure S38 TGA curves of Mn-salen catalysts $\left(10{ }^{\circ} \mathrm{C} / \mathrm{min}\right.$, in $\left.\mathrm{N}_{2}\right)$. 


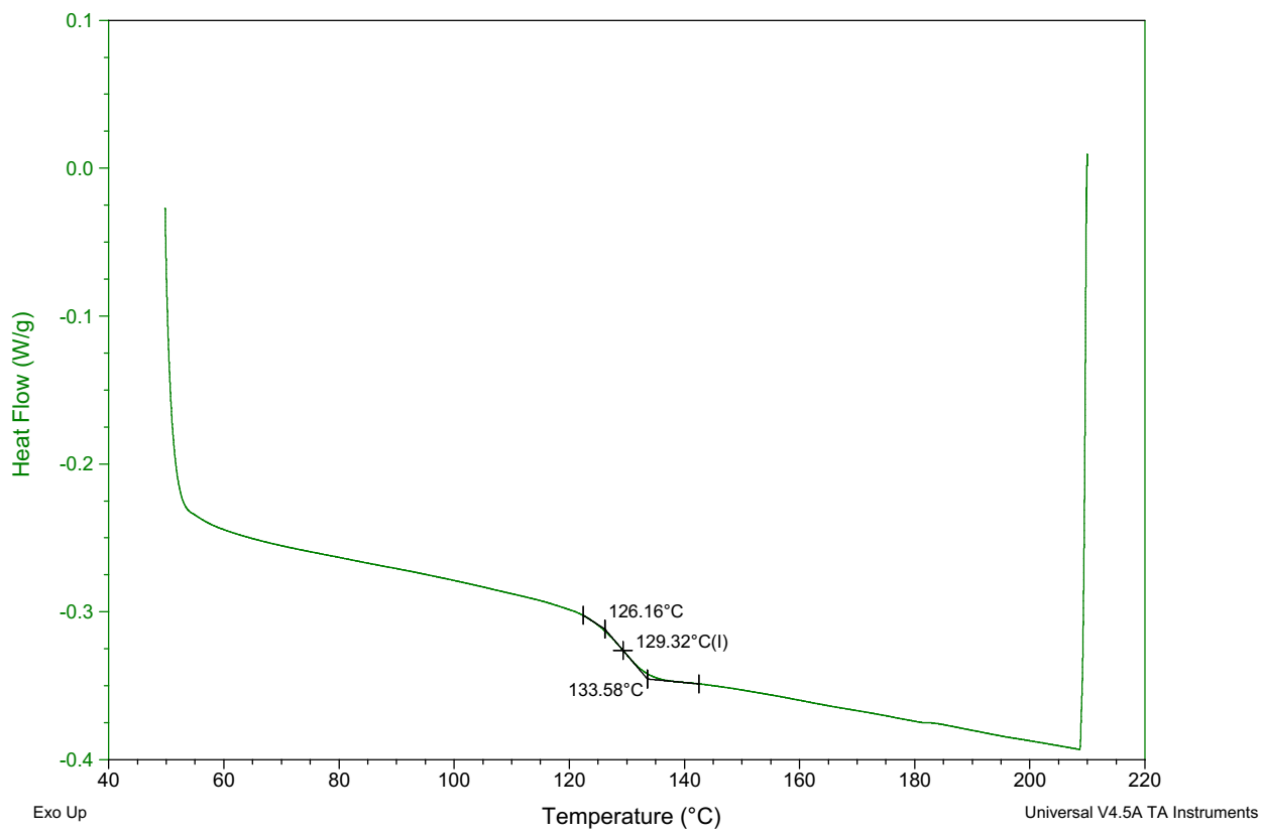

Figure S39 DSC of the cross-linked 5b/pyromellitic dianhydride copolymer generated in Scheme S1.

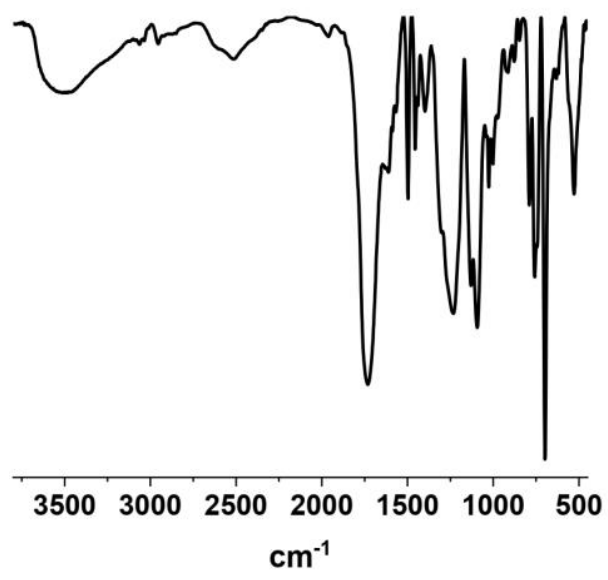

Figure S40 FT-IR data of the cross-linked $\mathbf{5 b}$ /pyromellitic dianhydride copolymer generated in Scheme $\mathrm{S} 1\left(v_{\mathrm{C}=\mathrm{O}}=1736 \mathrm{~cm}^{-1}\right)$. 


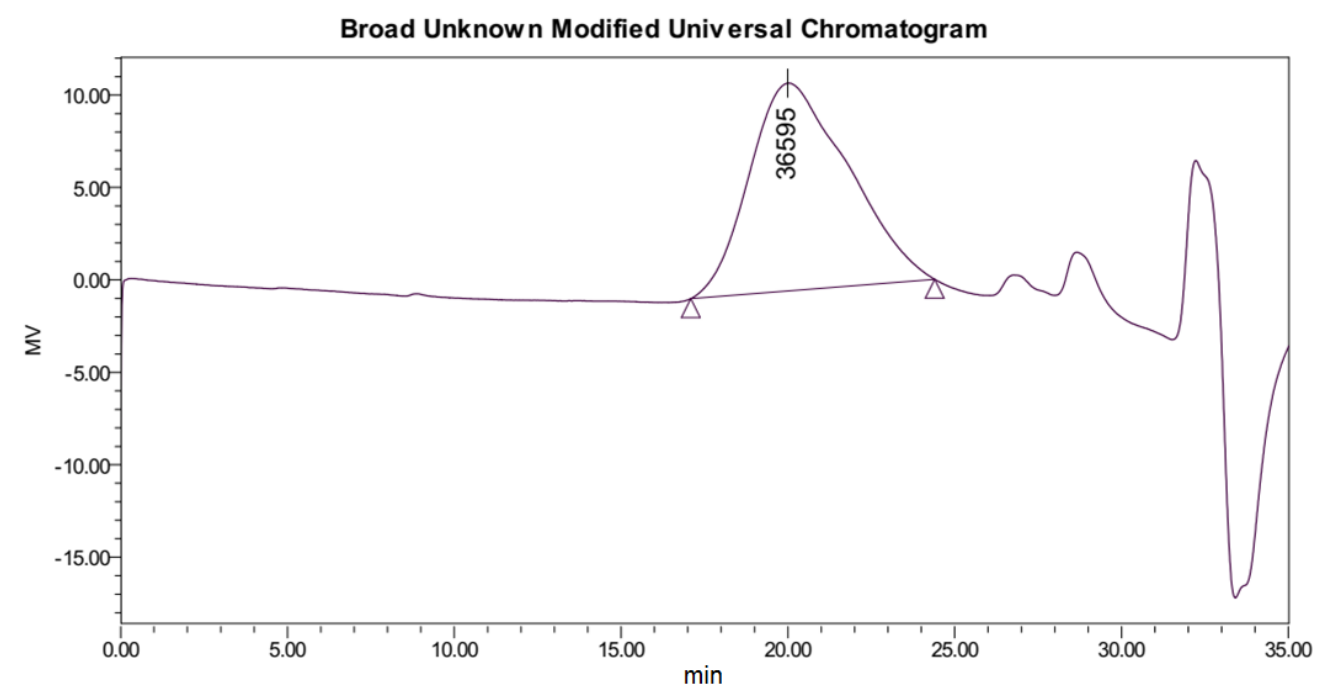

\begin{tabular}{|c|c|c|c|c|c|c|c|c|c|c|c|c|}
\hline \multicolumn{13}{|c|}{ Broad Unknown Modified Universal Peak Table } \\
\hline & $\begin{array}{c}\text { Distribution } \\
\text { Name }\end{array}$ & $\begin{array}{c}\mathrm{Mv} \\
\text { (Daltons) }\end{array}$ & $\begin{array}{c}\mathrm{K} \\
(\mathrm{dll} / \mathrm{g})\end{array}$ & alpha & \begin{tabular}{|c|} 
Intrinsic \\
Viscosity \\
(dl/g)
\end{tabular} & $\begin{array}{c}\text { Mn } \\
\text { (Daltons) }\end{array}$ & $\begin{array}{c}\text { Mw } \\
\text { (Daltons) }\end{array}$ & $\begin{array}{c}\text { MP } \\
\text { (Daltons) }\end{array}$ & $\begin{array}{c}\mathrm{Mz} \\
\text { (Daltons) }\end{array}$ & $\begin{array}{c}\mathrm{Mz}+1 \\
\text { (Daltons) }\end{array}$ & Polydispersity & $\mathrm{Mz} / \mathrm{Mw}$ \\
\hline 1 & & & & & & 21420 & 36881 & 36595 & 58329 & 82313 & 1.721801 & 1.581539 \\
\hline
\end{tabular}

Figure S41 Representative SEC of 1a/1b copolymer (Table 1, entry 4).

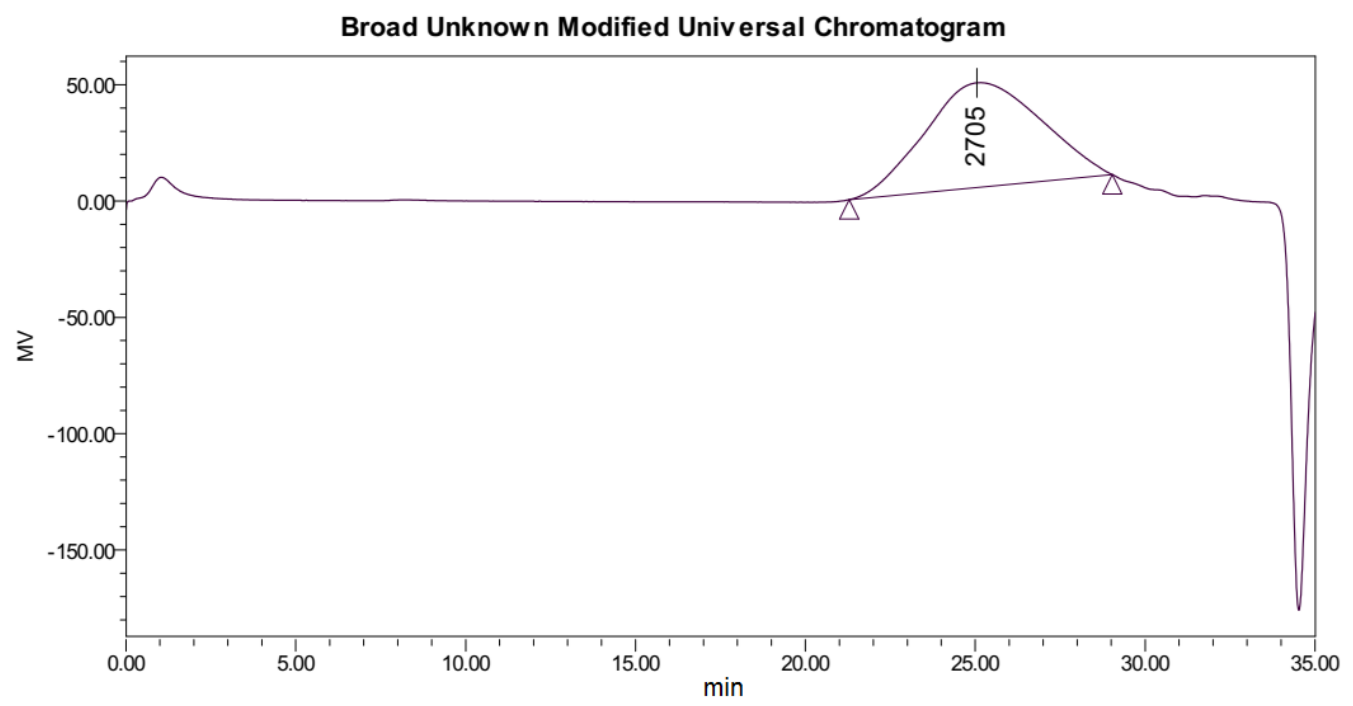

Broad Unknown Modified Universal Peak Table

\begin{tabular}{|l|c|c|c|r|r|r|r|r|r|r|r|r|}
\hline & $\begin{array}{c}\text { Distribution } \\
\text { Name }\end{array}$ & $\begin{array}{c}\text { Mv } \\
\text { (Daltons) }\end{array}$ & $\begin{array}{c}\mathrm{K} \\
\text { (dl/g) }\end{array}$ & alpha & $\begin{array}{c}\text { Intrinsic } \\
\text { Viscosity } \\
\text { (dl/g) }\end{array}$ & $\begin{array}{c}\text { Mn } \\
\text { (Daltons) }\end{array}$ & $\begin{array}{c}\text { Mw } \\
\text { (Daltons) }\end{array}$ & $\begin{array}{c}\text { MP } \\
\text { (Daltons) }\end{array}$ & $\begin{array}{c}\text { Mz } \\
\text { (Daltons) }\end{array}$ & $\begin{array}{c}\text { Mz+1 } \\
\text { (Daltons) }\end{array}$ & Polydispersity & Mz/Mw \\
\hline 1 & & & & & & 3840 & 4614 & 2705 & 5750 & 7172 & 1.201463 & 1.246279 \\
\hline
\end{tabular}

Figure S42 Representative SEC of $\mathbf{1 a / 1 b}$ copolymer (Table 1, entry 5). 


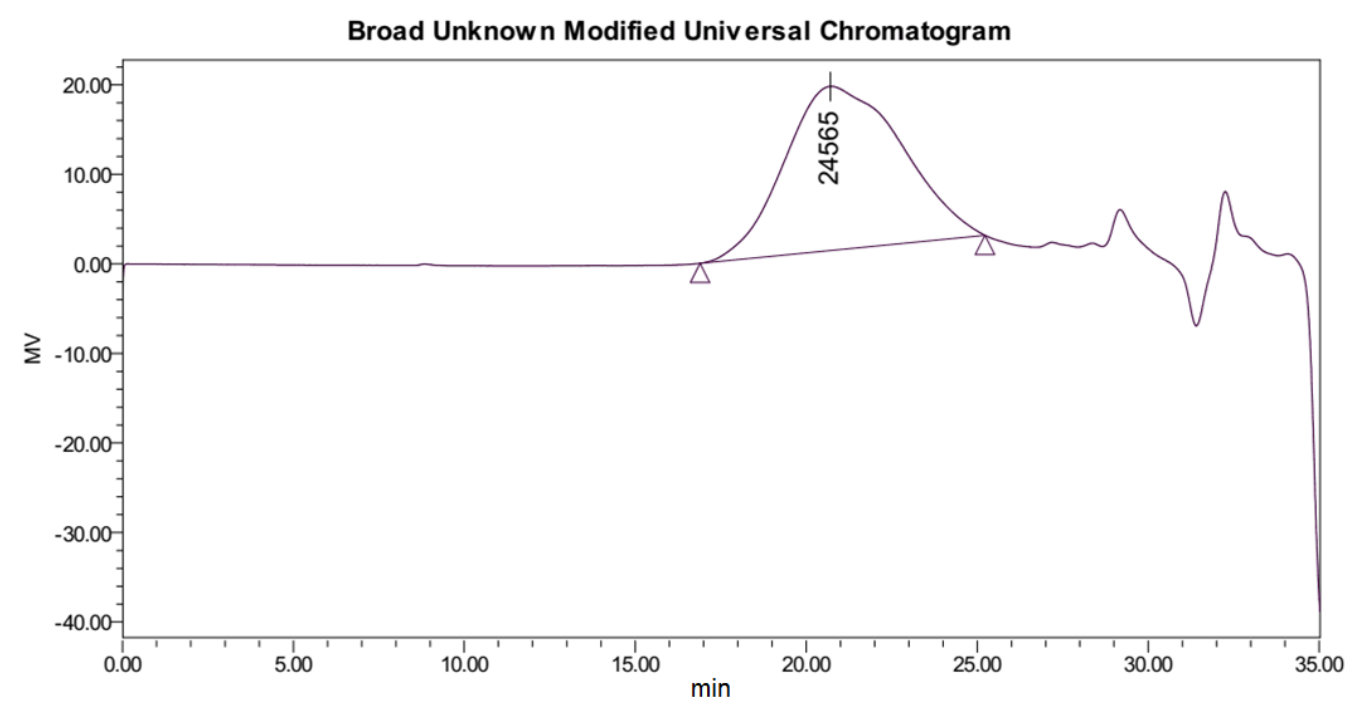

Broad Unknown Modified Universal Peak Table

\begin{tabular}{|c|c|c|c|c|c|r|r|r|r|r|r|r|}
\hline & $\begin{array}{c}\text { Distribution } \\
\text { Name }\end{array}$ & $\begin{array}{c}\text { Mv } \\
\text { (Daltons) }\end{array}$ & $\begin{array}{c}\mathrm{K} \\
\text { (dl/g) }\end{array}$ & alpha & $\begin{array}{c}\text { Intrinsic } \\
\text { Viscosity } \\
\text { (dl/g) }\end{array}$ & $\begin{array}{c}\text { Mn } \\
\text { (Daltons) }\end{array}$ & $\begin{array}{c}\text { Mw } \\
\text { (Daltons) }\end{array}$ & $\begin{array}{c}\text { MP } \\
\text { (Daltons) }\end{array}$ & $\begin{array}{c}\text { Mz } \\
\text { (Daltons) }\end{array}$ & $\begin{array}{c}\text { Mz+1 } \\
\text { (Daltons) }\end{array}$ & Polydispersity & Mz/Mw \\
\hline 1 & & & & & & 14411 & 26868 & 24565 & 48115 & 76271 & 1.864403 & 1.790793 \\
\hline
\end{tabular}

Figure S43 Representative SEC of epoxy-functionalized 1a/1b copolymer (Table S1, entry 5).

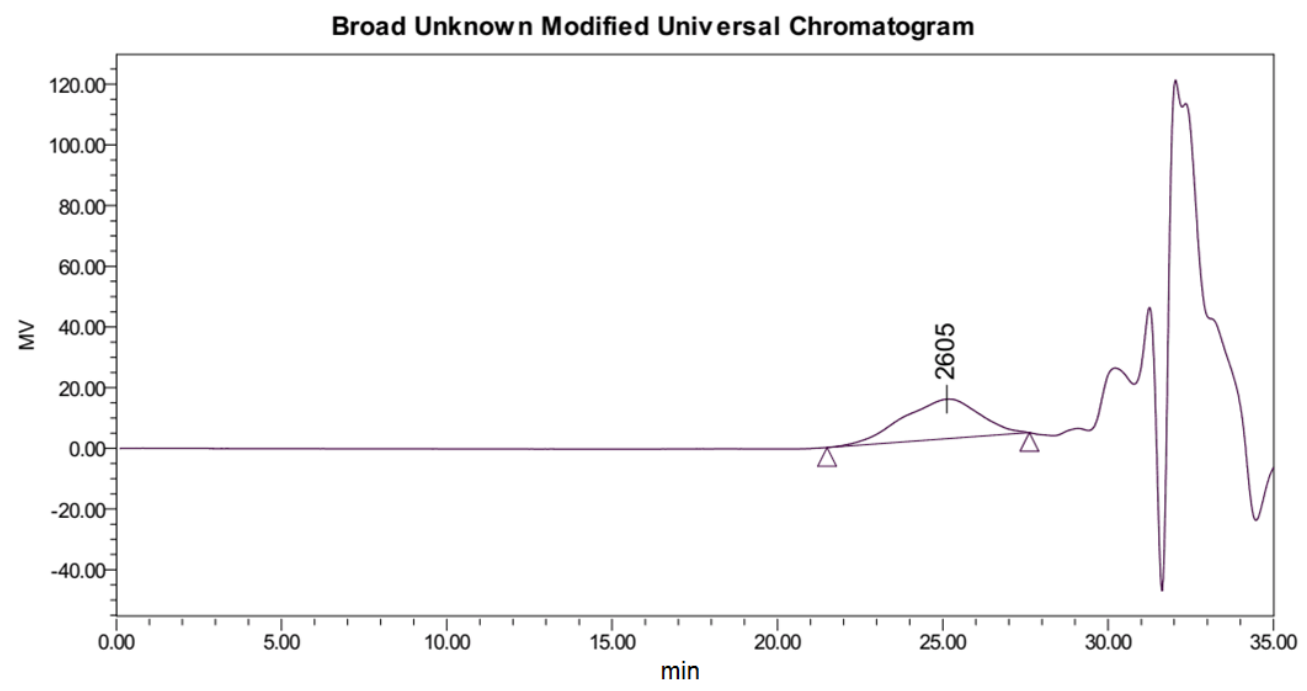

Broad Unknown Modified Universal Peak Table

\begin{tabular}{|l|c|c|r|r|r|r|r|r|r|r|r|r|}
\hline & $\begin{array}{c}\text { Distribution } \\
\text { Name }\end{array}$ & $\begin{array}{c}\text { Mv } \\
\text { (Daltons) }\end{array}$ & $\begin{array}{c}\mathrm{K} \\
\text { (dl/g) }\end{array}$ & alpha & $\begin{array}{c}\text { Intrinsic } \\
\text { Viscosity } \\
\text { (dl/g) }\end{array}$ & $\begin{array}{c}\text { Mn } \\
\text { (Daltons) }\end{array}$ & $\begin{array}{c}\text { Mw } \\
\text { (Daltons) }\end{array}$ & $\begin{array}{c}\text { MP } \\
\text { (Daltons) }\end{array}$ & $\begin{array}{c}\text { Mz } \\
\text { (Daltons) }\end{array}$ & $\begin{array}{c}\text { Mz+1 } \\
\text { (Daltons) }\end{array}$ & Polydispersity & Mz/Mw \\
\hline 1 & & & & & & 3629 & 4189 & 2605 & 4977 & 5976 & 1.154258 & 1.188018 \\
\hline
\end{tabular}

Figure S44 Representative SEC of epoxy-functionalized 1a/1b copolymer (Table S1, entry 8 ). 


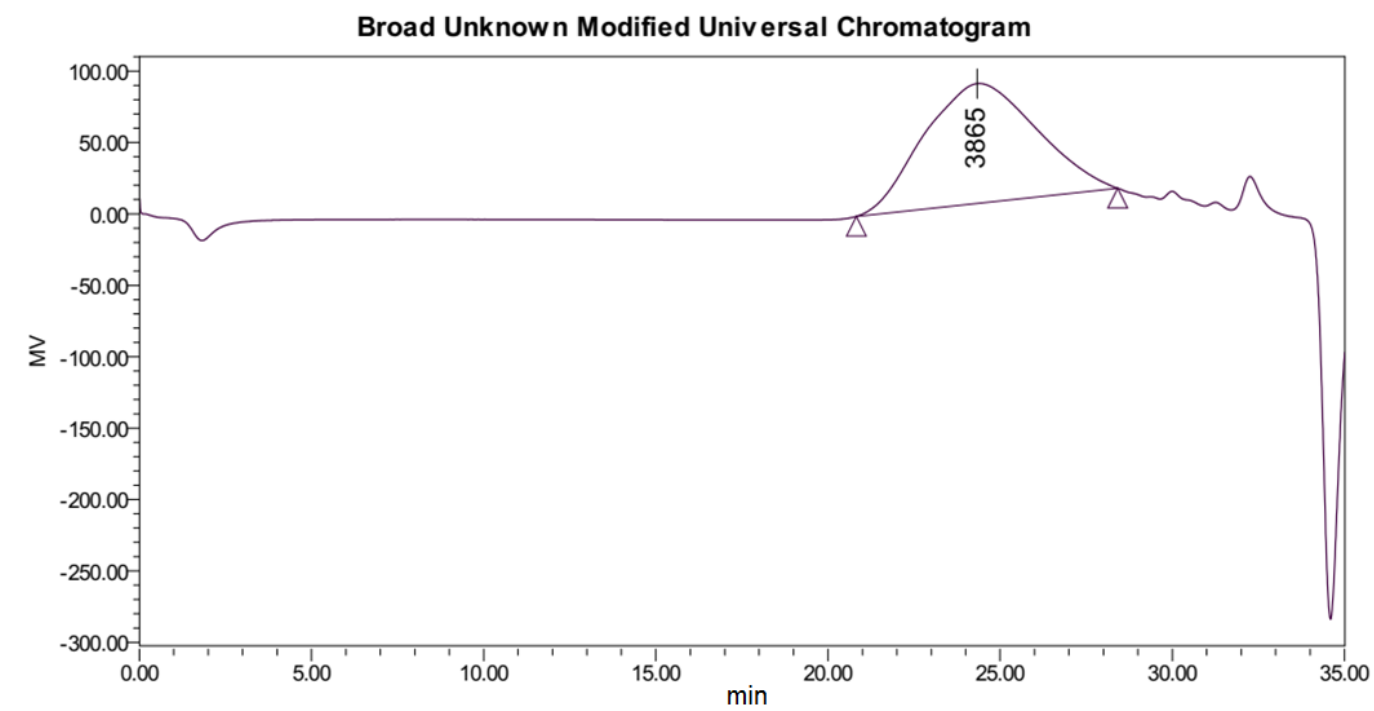

Broad Unknown Modified Universal Peak Table

\begin{tabular}{|l|c|c|c|c|c|r|r|r|r|r|r|r|}
\hline $\begin{array}{c}\text { Distribution } \\
\text { Name }\end{array}$ & $\begin{array}{c}\mathrm{Mv} \\
\text { (Daltons) }\end{array}$ & $\begin{array}{c}\mathrm{K} \\
\text { (dl/g) }\end{array}$ & alpha & $\begin{array}{c}\text { Intrinsic } \\
\text { Viscosity } \\
\text { (dl/g) }\end{array}$ & $\begin{array}{c}\mathrm{Mn} \\
\text { (Daltons) }\end{array}$ & $\begin{array}{c}\mathrm{Mw} \\
\text { (Daltons) }\end{array}$ & $\begin{array}{c}\mathrm{MP} \\
\text { (Daltons) }\end{array}$ & $\begin{array}{c}\mathrm{Mz} \\
\text { (Daltons) }\end{array}$ & $\begin{array}{c}\mathrm{Mz}+1 \\
\text { (Daltons) }\end{array}$ & Polydispersity & $\mathrm{Mz} / \mathrm{Mw}$ \\
\hline 1 & & & & & & 4427 & 5624 & 3865 & 7310 & 9263 & 1.270191 & 1.299809 \\
\hline
\end{tabular}

Figure S45 Representative SEC of the linear $\mathbf{5 b} /$ phthalic anhydride copolymer generated in Scheme S1. 


\section{References}

1. J. F. Larrow, E. N. Jacobsen, Org. Synth. 1998, 75, 1-11.

2. N. J. van Zee, G. W. Coates, Angew. Chem. Int. Ed. 2015, 54, 2665-2668. 